\title{
Structures and mechanisms in chemical reactions: George A. Olah's life-long search of chemistry
}

\author{
Istvan Hargittai ${ }^{1}$
}

Published online: 18 August 2016

(C) Springer Science+Business Media New York 2016

\begin{abstract}
The Hungarian-born American chemistry Nobel laureate George A. Olah used superacids to give longer life to carbocations. He resolved a long-standing debate on reaction mechanism in organic chemistry and, more importantly, opened new vistas in hydrocarbon chemistry to produce hosts of new compounds. The concerted utilization of organic synthesis, physical techniques, and computational methods led to spectacular achievements in hydrocarbon chemistry. Olah has always been on the lookout for the practical applications of his discoveries in fundamental chemistry. He continued his research after his Nobel award and has worked out the idea, which he labeled "the methanol economy." Olah's example shows that a great researcher can also be a devoted and caring human being.
\end{abstract}

Keywords George A. Olah - Carbocations - Superacids . Hydrocarbon chemistry $\cdot$ Reaction mechanism · Methanol economy

The realization of the electron donor ability of shared electron pairs could one day rank equal in importance with $G$. N. Lewis' realization of the electron donor unshared pairs.

George A. Olah [1]

This contribution is dedicated to George A. Olah in celebration of the forthcoming 90th birthday of this great scientist and wonderful friend.

Istvan Hargittai

istvan.hargittai@gmail.com

1 Department of Inorganic and Analytical Chemistry, Budapest University of Technology and Economics, POBox 91, 1521 Budapest, Hungary

\section{Introduction}

In 1962, George A. Olah (Fig. 1) delivered an invited talk at the Brookhaven Organic Reaction Mechanism Conference. He had immigrated only 5 years before to North

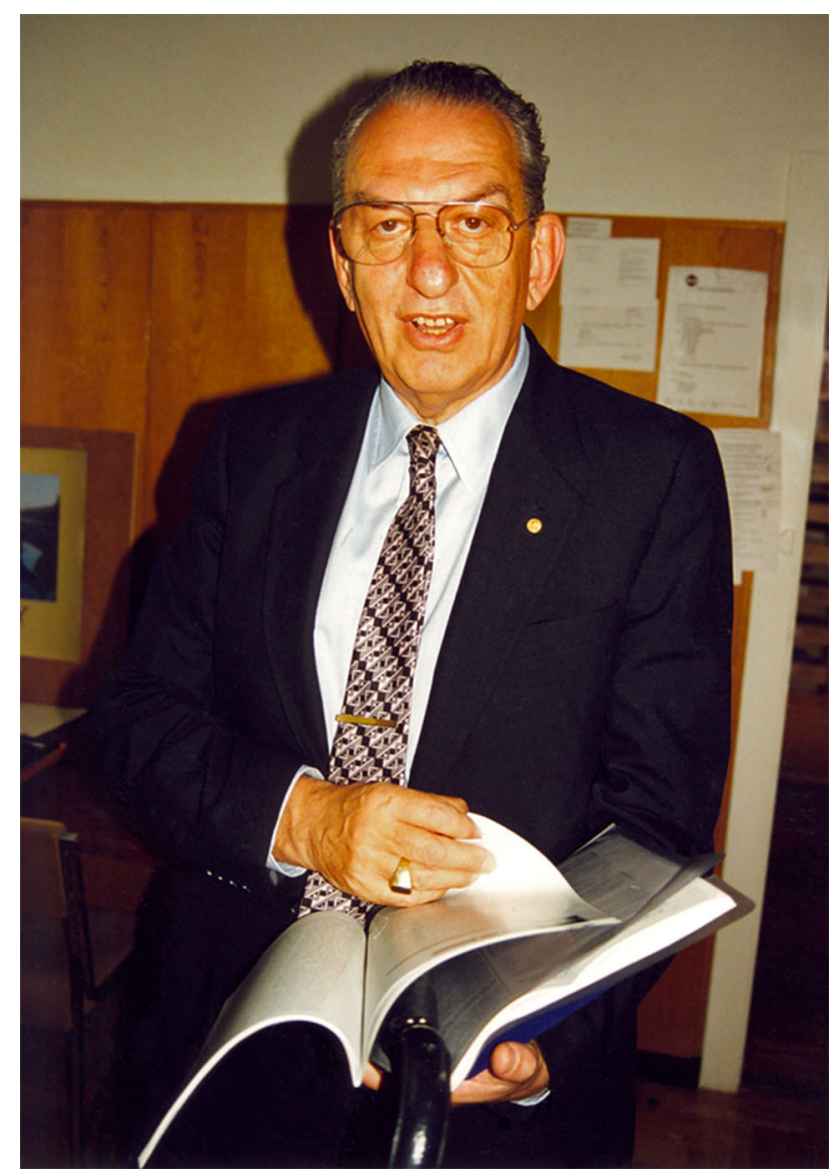

Fig. 1 George A. Olah in 1995 in the author's office at the Budapest University of Technology and Economics (photograph by the author) 


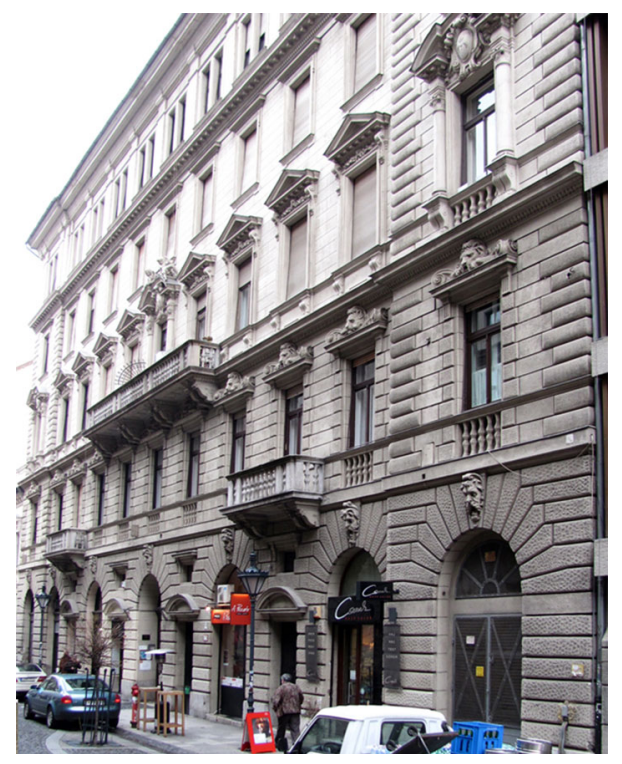

Fig. 2 The Olah family lived at 13-15 Hajós Street, District VI (photograph by the author), where George was born. It is just across the street from the Budapest Opera House

America and was working in a Canadian industrial laboratory. It was at the time of the famous debate about the reaction mechanism: whether the 2-norbornyl ion-an intermediate in the hydrolysis of the 2-norbornyl esters, for which there was significantly higher rate for the 2-exo versus the 2-endo derivatives - had a "non-classical" or a "classical" structure. Saul Winstein suggested that the "non-classical" ion had a bridged structure as a consequence of the sigma participation of the C1-C6 bond leading to electron delocalization. Herbert C. Brown ascribed the observed difference in the rate of hydrolysis to steric hindrance of the endo side causing rapidly equilibrating "classical" trivalent ions. Winstein and Brown were giants of organic chemistry and their public debates were popular spectacles of organic chemistry meetings.

In his lecture, Olah reported to have applied a new method of producing long-lived carbocations by means of superacids. Thus, he gave hope of resolving the longstanding 2-norbornyl ion controversy. The experimental observations concerning the rate difference in the hydrolysis of the 2-exo versus 2-endo-norbornyl esters had never been questioned. They were well established facts. The debate concerned the mechanism of the reaction. Uncovering the mechanism of a chemical reaction has been compared to uncovering Hamlet's story between the opening and closing acts of Shakespeare's drama [2]. Often, only the identities of the reactants and the products are known and the mechanism of the reaction leading from the reactants to the products need to be understood. There was solid evidence about the presence of cationic species in the reaction of hydrolysis of 2-norbornyl esters, but they were short-lived, "elusive," hence their nature and structure could not be determined. This is why Olah's claim of giving longer lives to such ions was so stirring. The two protagonists of the debate, Winstein and Brown each, separately, told Olah to be careful with his claim, citing the ease in which unsubstantiated claims could ruin a young chemist's promising career. Winstein and Bown also told Olah that should his claims prove true they expected him to come up with evidence supporting the "non-classical" (Winstein) and the "classical" (Brown) nature of the 2-norbornyl cation.

Eventually, and with the help of NMR spectroscopy and theoretical calculations, Olah provided unequivocal evidence in favor of the "non-classical" nature of the 2-norbornyl cation. The resolution of the famous debate was by itself not a pivotal achievement, but it enhanced Olah's visibility among his peers. Its real significance was in using superacids to produce long-lived, "persistent" carbocations. It pointed to the creation of a whole new chemistry involving hardly reactive hydrocarbons. The development of Olah's new chemistry happened in stages rather than in outbursts of earthshaking discoveries. Olah took his growing fame with attractive humility. He must have felt enormous inner satisfaction though when looking back to the road leading to this exalted status in his science. That road was anything but easy and uneventful.

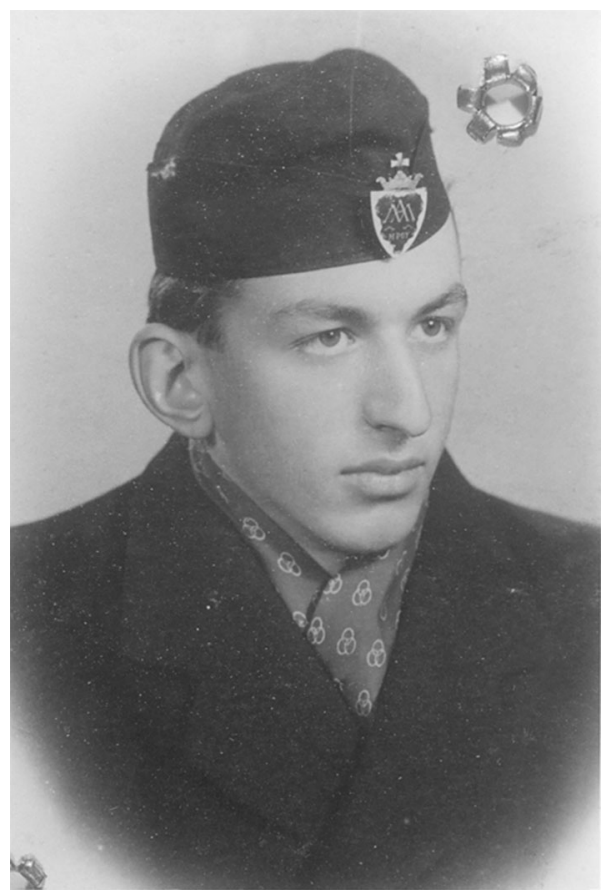

Fig. 3 George A. Olah as a high school student (courtesy of George A. Olah) 


\section{The beginnings}

George A. Olah was born (as György Oláh, on May 22, 1927) into an upper-middle-class intellectual family. His father was a lawyer and the family lived in downtown Budapest. The house (Fig. 2) in which they lived in an apartment stood across from the Budapest Opera House. George attended good schools. In particular, for high school, he attended the Gimnázium of the Piarist Order (Fig. 3). The Catholic Piarist Order has taught in Pest since 1717 (Figs. 4, 5). The school boasts another chemistry Nobel laureate among its graduates, George de Hevesy (or Georg von Hevesy, depending on the language he was using). Hevesy attended this school between 1895 and 1903. Hevesy was Jewish and his family converted at around the time of his graduation or soon after.

Olah was looking forward to a pleasant and fulfilling life with whatever he would choose for a profession. Everything was given for him, except security as Europe and Hungary were rapidly moving toward World War II. As he was growing up, especially during his upper classes in high school, racial laws of increasing severity were threatening not only his well-being, but eventually even his life. We are circumspect in describing these years of his life in accordance with his own tacit wishes. When in 1957, he, his wife, and their first child immigrated to North America, he and his wife felt they could leave behind all the unpleasantness and horrors of their lives in Hungary. He expressed this in a letter to a friend in Budapest in 2003, “... My life is a life of an American of Hungarian origin, and I am no longer living in the shadow of the [anti-Semitic] Nuremberg Laws" [3]. In his autobiography, he devotes a single, though poignant, sentence to this period: "I do not want to relive here in any detail some of my very difficult, even horrifying, experiences of this period, hiding out the last months of the war in Budapest" ([4], p 45).
In 2003, Olah received an award from the University of Szeged, the Klebelsberg Prize, honoring the memory of the long-time minister of religion and public education. Kuno Klebelsberg had a broad vision for the dominance of Hungary in the region through Hungarian 'cultural superiority,' which was an expression of blatant nationalism. This included a desire to regain territories referred to as Greater Hungary, racism and in particular anti-Semitism.

He aimed at bringing back some of the talent that had left Hungary, but he did not include the Jewish expatriates in the circle of those he wanted to return to Hungary. There was an irony in Olah's receiving the Klebelsberg Prize. It is highly doubtful whether Olah could have had a career in academia under Klebelsberg's reign of culture and education in the anti-Semitic Horthy regime that lasted in Hungary for 25 years, between 1920 and 1944.

In their tolerance, the Piarists built on their liberal traditions. At the time of the Holocaust, the school meant to exclude persecution within its walls and had its Jewish students remove the yellow star from their clothing. However, eventually, Olah had to seek refuge outside the school and Olah's above quoted sentence referred to this last period.

During the Hungarian Holocaust, representatives of a number of nations distinguished themselves in saving lives, and there were a number of Hungarian saviors as well. Gábor Sztehlo was a Lutheran minister who responded to the Lutheran Bishop Sándor Raffay's call to save persecuted Jewish children who had converted, and Sztehlo organized protective homes for them (Figs. 6, 7). The high school student Olah was among his charges. Soon, Sztehlo extended his efforts to all Jewish children and eventually to all children that he found abandoned as he continued his activities after liberation. In 1972, Yad Vashem granted Sztehlo the title "Righteous among the Nations" [5].
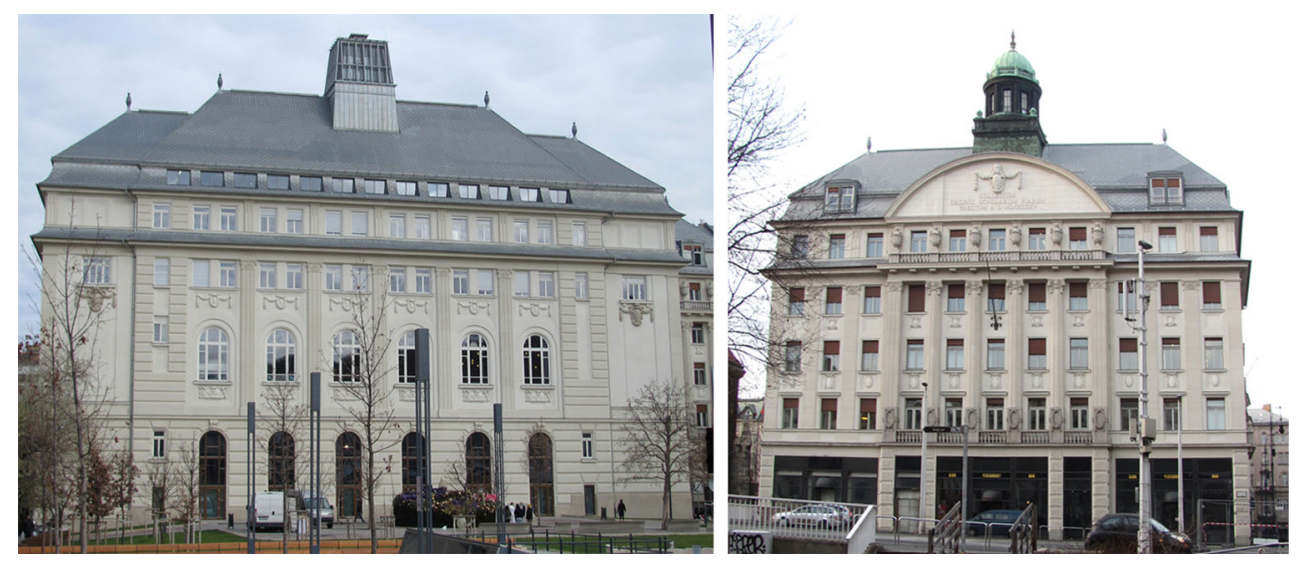

Figs. 4, 5 The two principal buildings of the recently renovated Gimnázium of the Piarist Order at the Pest bridgehead of Erzsébet [Elizabeth] Bridge (photographs by the author) 

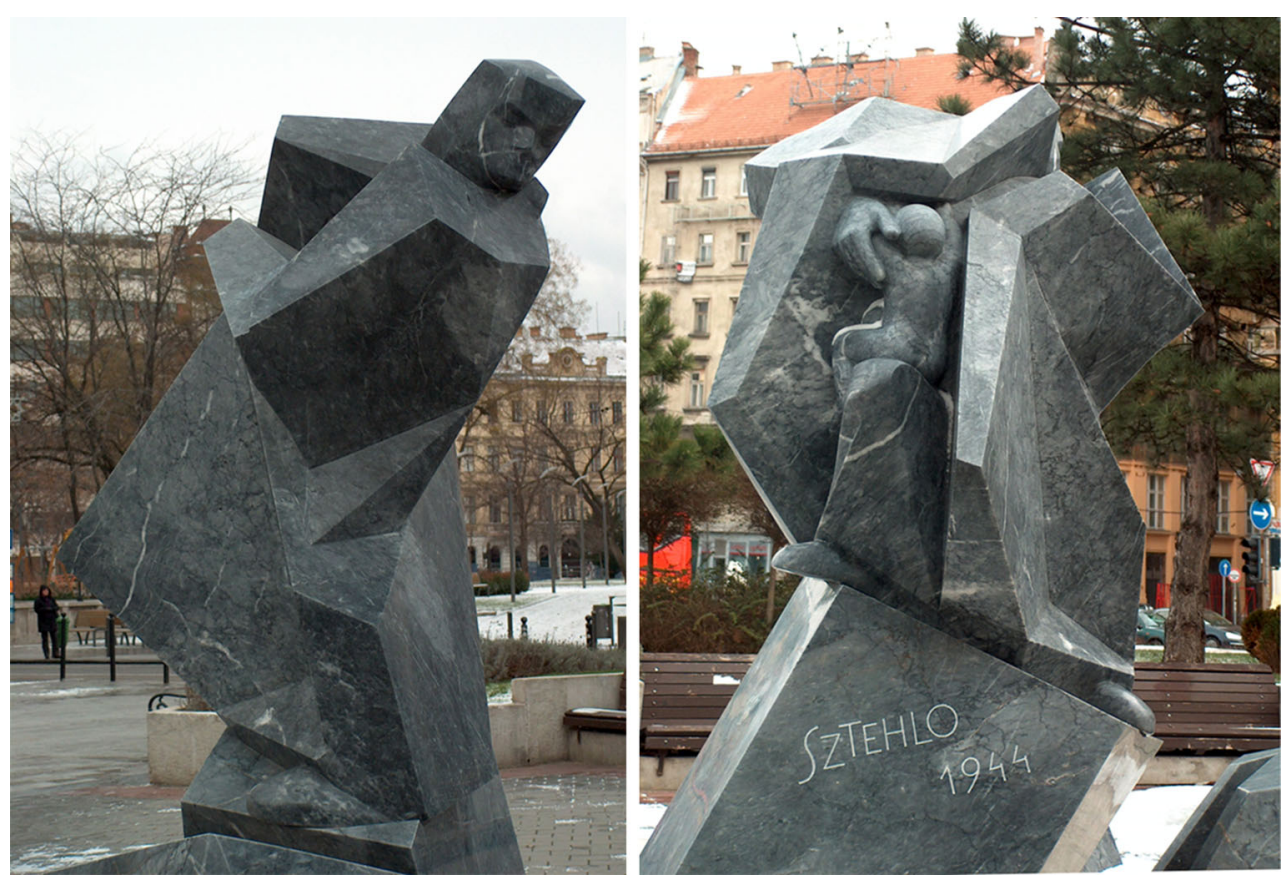

Figs. 6, 7 Two views of the Gábor Sztehlo statue (erected in 2009) on Deák Ferenc Square, District V, by Tamás Vigh and Barnabás Winkler. Photographs by the author

George's brother, Peter, three years his senior, did not survive the war. He had also been a student of the Piarists, which he attended between 1934 and 1942. His name is listed among the martyrs of the school of the period 1938-1958 on a memorial plaque in the lobby of the school.

When the Hungarian legislation had ordered the Hungarian high schools to restrict the number of Jewish pupils for the academic year 1943/1944, the Piarists ignored these restrictions except for the first-graders. They did not send away any of the upper-class pupils. The Arrow-Cross (Hungarian Nazi movement) took over the government on October 15, 1944, and the school closed for a few days. The instruction stopped entirely from October 25. It resumed on March 12, 1945. There were some new teachers and some classes were combined. The yearbook of the school lists the names of the pupils that never returned. George completed his studies at the Gimnázium of the Piarist Order in the spring of 1945 (Fig. 8). The school, keeping with its academic standards and regardless of the immediate post-war conditions, instituted a demanding final examination.

The sentence quoted above from Olah's autobiography about placing the painful experience of his Hungarian period behind him should not be interpreted as indifference to political and other developments in Hungary. He has remained conscious and proud of his Hungarian roots. $\mathrm{He}$ has observed keenly and critically the recent political developments in Hungary that include the restoration of

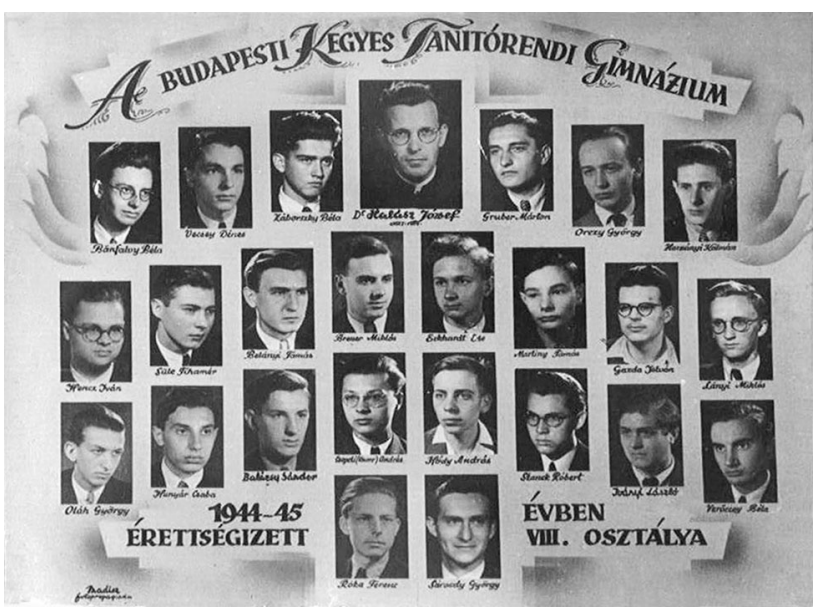

Fig. 8 Graduates of Olah's Class 1945; Olah's portrait is in the lower left corner (courtesy of the Gimnázium of the Piarist Order)

much of the spirit of the Horthy regime between the two world wars. He finds it especially painful that the Hungarian responsibility for past tragedies has still not been faced [6].

\section{Start of a career}

Up to his graduation from high school, Olah had been especially interested in literature and history and he had not planned a career in the hard sciences. When in 1996, soon after his Nobel award, the periodical Chemistry \& Industry 
asked him, "If you hadn't become what you are, what else would you most likely to have been?," Olah's response was, "Writer, historian" [7]

His experiences and the post-war conditions in Hungary, however, prompted him to rethink the direction he was going to take. One generation before him, other future great scientists had to face similar dilemmas. Eugene P. Wigner, for example, was interested in becoming a physicist and John von Neumann, a mathematician. However, parental advice directed each of them to earn a diploma in chemical engineering first as it was offering a more secure future than physics or mathematics at the time as far as jobs were concerned. Olah chose chemical engineering rather than history or literature, and once he became engaged to chemistry, he never left it (Figs. 9, 10).

The Budapest Technical University (today, Budapest University of Technology and Economics) had an academically very strong Faculty of Chemical Engineering (today, Faculty of Chemical Technology and Biotechnology). There was and has been as much emphasis on learning basic chemistry as on the subjects more directly related to technology. By all available information, Olah enjoyed his studies and valued the direct interactions with his teachers. A reviewer of his autobiography noted: "Lectures, albeit compulsory, by active professors so inspired him that he continues to advocate a historical perspective in teaching and, despite the accessibility of electronic communication, direct teacher-student interaction in informal lectures" [8].

It took four years - eight semesters - of structured and intensive studies to earn the Diploma of Chemical Engineer (Fig. 11). Immediately upon graduation, in June 1949, Olah was appointed assistant professor at the Institute of Organic Chemistry of the Technical University. Géza Zemplén (1883-1956, Fig. 12), a former disciple of the

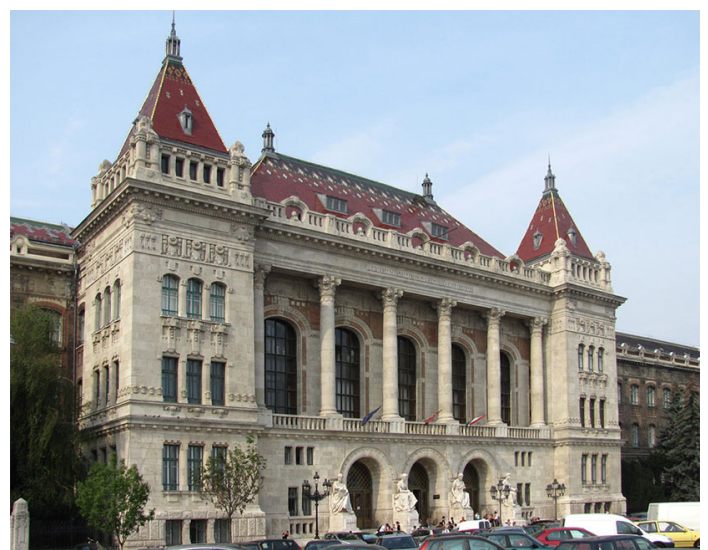

Fig. 9 The middle section of the central building " $K$ " of the Budapest University of Technology and Economics, 1-3 Müegyetem Quay, District XI (the building was inaugurated in 1909). Photograph by the author

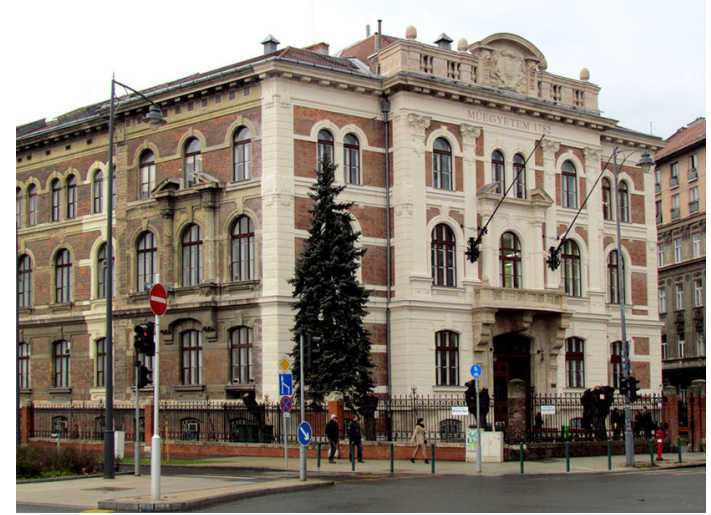

Fig. 10 The chemistry building " $\mathrm{CH}$ " of the Budapest University of Technology and Economics, 4 St. Gellért Square, District XI (it was built in 1902 and houses about half of the chemistry faculty). Photograph by the author

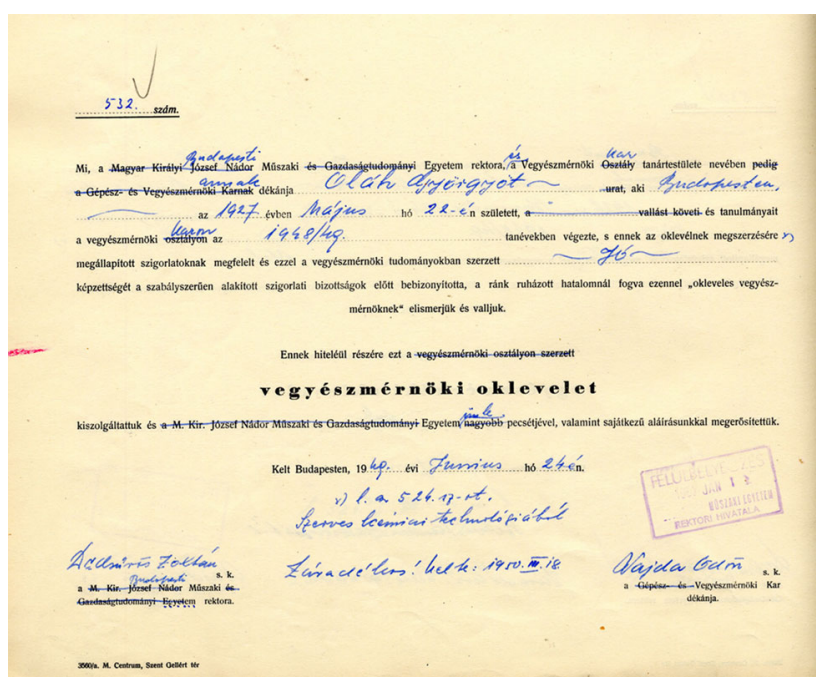

Fig. 11 Copy of George A. Olah's (György Oláh) Diploma of Chemical Engineer dated June 24, 1949; the grade is "good," the final examination was in organic chemistry technology. The many amendments of the printed form were due to the fact that in 1949, the school was still using pre-war printed forms (courtesy of the Library of the Budapest University of Technology and Economics)

great German organic chemist Emil Fischer in Berlin did postdoctoral studies (using today's term) with Emil Fischer in 1907 and 1908-1910. Zemplén was Professor of Organic Chemistry at the Budapest Technical University from 1913 until his death, and from 1950, he was the head of the Institute of Organic Chemistry of the University. He was the principal figure in organic chemistry in Hungary. His main interest was carbohydrate chemistry and did a great deal of work for pharmaceutical companies as well. Zemplén proved to be a good mentor who could serve as a knowledgeable example but who let Olah go his own way 


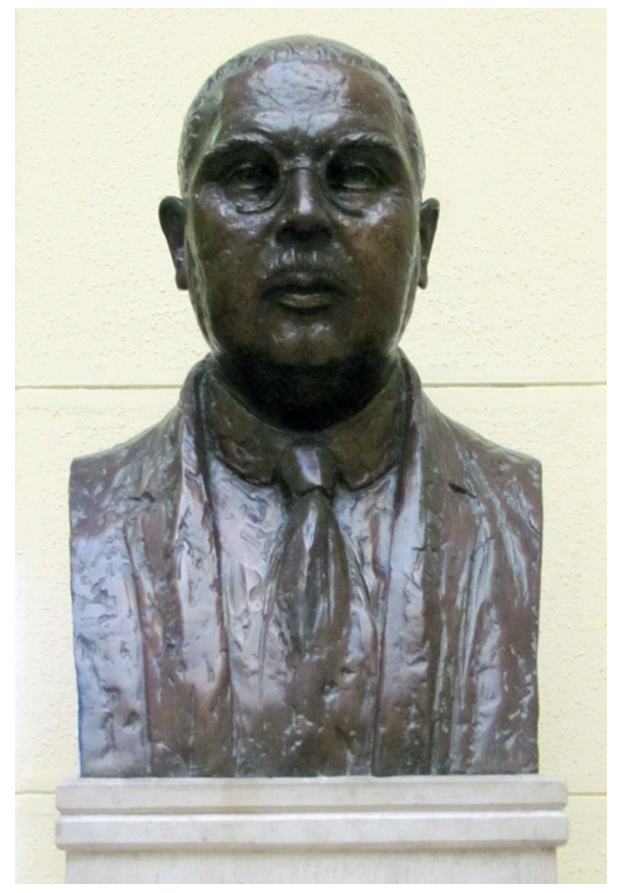

Fig. 12 Bust of Géza Zemplén in the aula of the central building " $K$ " of the Budapest University of Technology and Economics (photograph by the author)

when Olah wanted to develop an independent research line in fluoro-organic chemistry.

Olah excelled from the start of his research career and in several aspects. He published papers that caught the attention of foreign researchers; he, with a colleague, compiled the index to an organic chemistry text; embarked on writing a book on theoretical organic chemistry; and did his share of teaching. In the years 1950 and 1951 Olah's primary research focus was in carbohydrate chemistry - the area of Professor Zemplén's studies. From 1951, Olah developed his independent line of research.

Soon after graduation at the Technical University, Olah applied for and was granted a scholarship for doing his postgraduate work in a structured framework. This led to the scientific degree, which used to be called "Candidate of Science" following the Soviet example. For all practical purpose, it was equivalent to a $\mathrm{PhD}$ degree in a good western university, but it was not granted by a university; rather it was granted by a special degree-granting institution of the Hungarian Academy of Sciences. Olah did all his research at the Technical University, submitted his dissertation in 1953, and defended it in 1954. The dissertation was about the chemistry of organic fluorine compounds; it is in Hungarian; and a copy of it is stored in the Manuscript Collection of the Hungarian Academy of Sciences, available for inspection. It consists of 186 pages with a vast amount of hand-drawn formulae and reaction equations, and it reports about a tremendous amount of innovative synthetic work. The working conditions were poor, the reactants that elsewhere might have been readily available often had to be prepared from scratch, but the work is overwhelmingly impressive.

In his thesis work, Olah applied techniques and procedures of organic fluorine chemistry practiced already elsewhere and invented new techniques and procedures as well. He constructed what he called a Freon reactor (Fig. 13), a technique for fluorinating carbon tetrachloride and chloroform under ultraviolet irradiation using $\mathrm{NaF}, \mathrm{KF}$, and $\mathrm{CaF}_{2}$. He produced chlorofluorocarbons in continuous operation. Olah listed 16 entries as publications containing the materials of his dissertation. They include a series of 12 papers most of which appeared parallel in Hungarian and in English (the latter in the English-language chemistry journal of the Hungarian Academy of Sciences, Acta Chimica Hungarica, which no longer exists). In most of these papers, Attila Pavlath, then Olah's student, much later, President of the American Chemical Society, was a co-author. Two entries referred to Olah's inventions of new techniques and procedures for producing organic fluorine compounds, filed one each in 1952 and in 1953. In his summary, Olah stressed the importance of his inventions for the industrial production of Freon compounds. In addition, two entries among Olah's publications referred to papers co-authored with colleagues at the medical school about the impact of organic fluorine compounds on

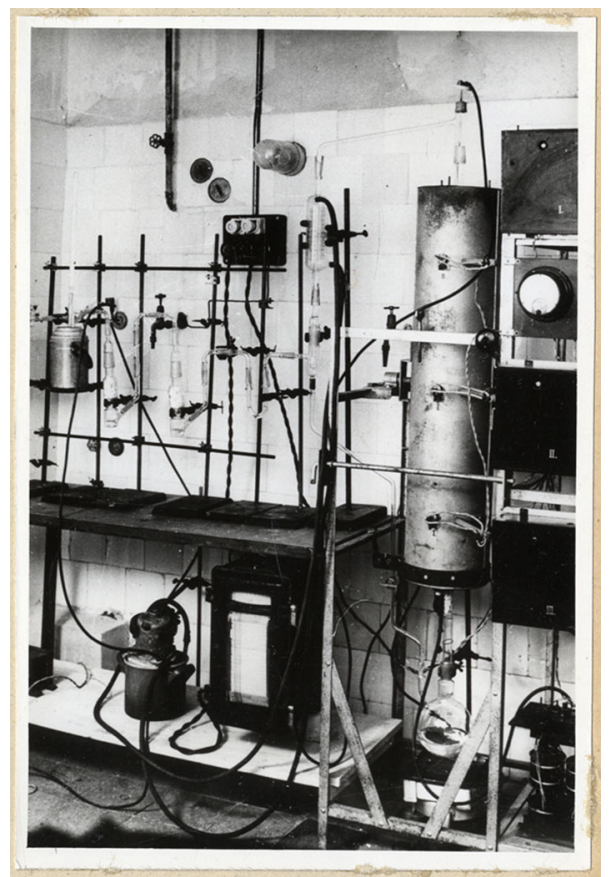

Fig. 13 Olah's "Freon reactor" constructed at the Budapest Technical University in the early 1950s as part of his thesis work (from George A. Olah's PhD-equvivalent dissertation; courtesy of George A. Olah and the Library of the Hungarian Academy of Sciences) 
experimentally induced tumors in animals. One of these two papers appeared in a German tumor research journal, the Archiv für Geschwulstforschung. Olah defended his dissertation and was granted the $\mathrm{PhD}$-equivalent Candidate of Science degree in June 1954.

Olah's interactions with his colleagues in the medical school were anything but superficial. He signed up and completed the first 3 years of the subjects in the medical school, passed the examinations and fulfilled other requirements. All this, he was doing in the years 1951-1953. Also in this period he studied the Russian language and passed the exam for the $\mathrm{PhD}$ candidates with flying colors. He had to take also the obligatory political subjects prescribed for the $\mathrm{PhD}$ candidates during this same period. Olah listed his working engagements as $64 \mathrm{~h}$ weekly, which included 14 contact hours with students. In reality his engagement was most probably more than $64 \mathrm{~h}$ per week.

In 1954, Olah was appointed deputy director of the newly organized Central Research Institute of Chemistry of the Hungarian Academy of Sciences. There, Olah found another worthy mentor in the director of the Institute, the physical chemist Géza Schay (1900-1991, Fig. 14). He was a former disciple (postdoc) of the great Hungarianborn physician-turned physical chemist (and later turned philosopher) Michael Polanyi in Berlin, in the years 1926-1928 and 1930. Schay was Professor of Physical Chemistry of the Budapest Technical University (1949-1965) and in 1954, he was appointed director of the new institute. Schay's primary interest in physical

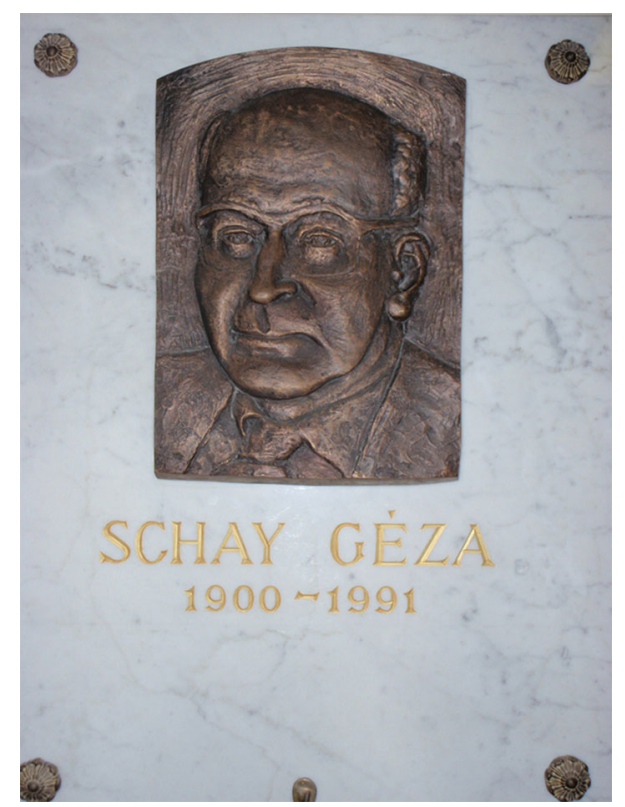

Fig. 14 Relief of Géza Schay in building "F" at the Department of Physical Chemistry of the Budapest University of Technology and Economics (photograph by the author) chemistry was thermodynamics and reaction kinetics, and in particular, adsorption.

Olah must have been working with improbable high intensity and efficiency. Within 2 years from 1954, having been awarded the Candidate of Science (PhD-equivalent) degree, in 1956 he submitted his dissertation for the Doctor of Science degree. This has no exact equivalent in the American system; it is not the same as the British DSc and it is more than the German habilitation. This was a degree in which substantial scientific research production had to be demonstrated and served as prerequisite for a professorial appointment. Furthermore, only those who possessed this degree could be considered for getting elected to the Science Academy. Olah was not yet 29 years old at the time. It sometimes happens that mathematicians produce such a dissertation at an early age, but I know of no other chemist having completed the Doctor of Science work at that age. Olah's dissertation is available for inspection at the Archives of the Hungarian Academy of Sciences. The Manuscript Collection and the Archives are two separate sections of the Library of the Academy. The Manuscript Collection stores the dissertations that had been defended, whereas the dissertations that have not been are stored in the Archives. Olah left Hungary before he could have completed the process of the defense.

Just like Olah's Candidate of Science dissertation, his Doctor of Science dissertation is also substantial. It is in Hungarian and its title in English translation is "Data for the mechanism of electrophilic reactions of aromatic substitution." Almost all publications on which his previous thesis was based appeared in Hungarian journals (even if they were published in English). In contrast, most of the papers for his DSc thesis appeared in important western periodicals, such as the British Nature and the Journal of the Chemical Society and the German Chemische Berichte and Naturwissenschaften. Almost all of these papers were co-authored by Olah and his students, Attila Pavlath and Istvan (later, Steven) Kuhn.

The period between 1949 and 1956-the years during which Olah operated in Hungary after graduation-were busy. He established joint research with colleagues at the medical school in Budapest, attended meetings and visited research laboratories in Switzerland, East Germany as well as West Berlin (as they were then), and the Soviet Union, among others. He met with outstanding scientists, such as the Germans Weygand and Bohlmann, the Czech Wichterle, the Romanian Nenitzescu, and the Russian Reutov, Nesmeyanov, Semenov, and Kitaigorodskii. All these Russian scientists were among the top in Soviet science, and not only scientifically. Nikolai N. Semenov was the founding director of the Institute of Chemical Physics of the Soviet Academy of Sciences and in 1956 he was to receive the Nobel Prize in Chemistry. Aleksandr N. 
Nesmeyanov was Professor of Organic Chemistry at Moscow State University, the director of the Institute of Organic Chemistry between 1939 and 1954, and from 1954, the director of the Institute of Element-Organic [Heterorganic] Compounds of the Soviet Academy of Sciences. More importantly, he was the President of the Soviet Academy of Sciences between 1951 and 1961. It was at the start of his tenure as president that there was a big conference in Moscow organized to condemn Linus Pauling's resonance theory and condemn its Soviet followers as well. It was part of Stalin's anti-science policies as the theory of resonance was considered as being against Marxist-Leninist dogma. Stalin's anti-science policies were in concurrence with his paranoiac anti-Semitic policies [9]. Olah sensed the impossibility of doing science freely in such an atmosphere and he mentions this in his autobiography.

Olah applied for and was awarded the Dutch van 't Hoff Fellowship (but had no opportunity to utilize it). Reviewing his activities and interactions at the time, his situation may be called exceptionally favorable among his peers. His complaint that "Isolation clearly was a most depressing aspect of pursuing science in Communist-dominated Hungary" ([4], p 62) becomes understandable only if considering the flurry of his later activities under freedom in Canada and the United States.

\section{Toward the summit}

In 1949, Olah married a colleague at the Technical University, Judit Lengyel (born in Budapest in 1929; Judit was later changed to Judith, Fig. 15). She was at the time a secretary at the University, but soon she studied chemical engineering and graduated from the Budapest Technical University. They shared a heavy burden of the recent past.

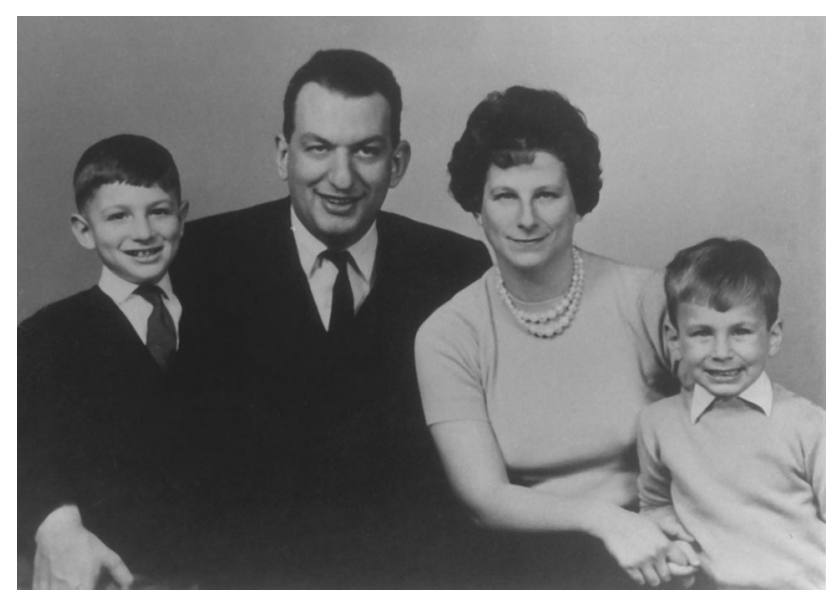

Fig. 15 The Olah family in 1962: George, Jr, George, Judith (Judy), and Ronald (Ron). Courtesy of George A. Olah
In 1944, the Red Cross helped Judit and her 22-year old sister hide in a convent. On December 17, the Hungarian Nazis took them and others and marched them through the city. In a brave moment Judit escaped from the column, went into hiding, and survived; her sister stayed in the column and perished.

Judith and George had a boy in 1954 and another boy after they immigrated to Canada. The Olahs left Hungary in November, shortly after the Soviet tanks suppressed the Hungarian Revolution of October 23, 1956, but the borders to the West remained open for a short while. After brief stops in Vienna and London-where Olah initiated valuable interactions with colleagues-they moved on to Canada. Olah started looking for a suitable job already in London and in this he was assisted by Ms. Esther Simpson of the Academic Assistance Council (AAC).

The AAC was formed in 1933 to help refugee scientists from Germany and it was initiated by William Beveridge, Leo Szilard, and a group of internationally renowned British scientists, with Ernest Rutherford as its first president. Ms. Simpson was already working for the organization at that time. The AAC had been renamed to the Society for the Protection of Science and Learning by the time Ms. Simpson was trying to help Olah. Today, the successor of AAC is the Council for At-Risk Academics and it still performs a much needed function.

The Olahs did not intend to stay in England; they were headed to Canada because they had close family connections there. Olah did not find employment in academia and started working in an industrial laboratory of the Dow Chemical Company in Sarnia, Ontario. Years later, when Olah had already become an internationally renowned scientist, a professor of organic chemistry at the University of Toronto apologized to him for opposing Olah's appointment to the University in 1957. Olah was unknown and this professor thought he was not worth the risk of employing him at the University of Toronto.

Olah found an industrial position and he has maintained ever since that "it is good to be challenged" [10]. Beside fulfilling the obligations of his job at the Dow laboratory, Olah continued his fundamental research he had begun in Hungary. In this industrial laboratory, he discovered ways to prolong the lifetime of carbocations and reached results that-again, showing Dow's magnanimity-he was allowed to publish. Olah's publications made an impact and resulted in his invitation to give a talk at the 1962 conference in Brookhaven I referred to in the Introduction. Furthermore, still at the time he was with the Dow Canadian laboratory, the American Chemical Society conferred upon him in 1964 its Award in Petroleum Chemistry.

The broader chemistry community recognized Olah's achievements over the years and the first impulses came through his decisive contribution to the resolution of the 
Winstein-Brown controversy (Figs. 16, 17). Gradually, a whole new chemistry was emerging from Olah's discoveries. His first pivotal results came from his works in the Dow laboratory in Canada, from where he moved to another Dow laboratory in Massachusetts. While in industry, Olah was doing everything to maintain his fundamental research and never lose connection with academia. His colleagues in academia responded to his efforts; they visited Olah's laboratory, invited him to participate in seminars and meetings, read and appreciated his papers, and attended the seminars he organized. Dow was good to him, but within limits. His research director did not recognize the significance of NMR spectroscopy and Olah had to bring or send his samples for NMR recording to university laboratories. However, this was another opportunity to enhance his interactions.

Back in his brief sojourn in London in 1957, he established interactions with the English chemist Ronald J. Gillespie (Fig. 18), one of Christopher Ingold's disciples. Ingold was Gillespie's mentor who helped enormously his associates, which was very good in the beginning of a research career, but became burdensome when it was time for Gillespie to establish his independence. Ingold was not the exploiting type and did not let his name figure on Gillespie's papers even when Ingold did write Gillespie's manuscript on the basis of Gillespie's investigation. However, Gillespie was told by Ingold who his graduate students should be, what apparatus to acquire next time, and so on. When an opportunity arose for a fully independent position at McMaster University in Canada, combined with the possibility of acquiring the most up-to-

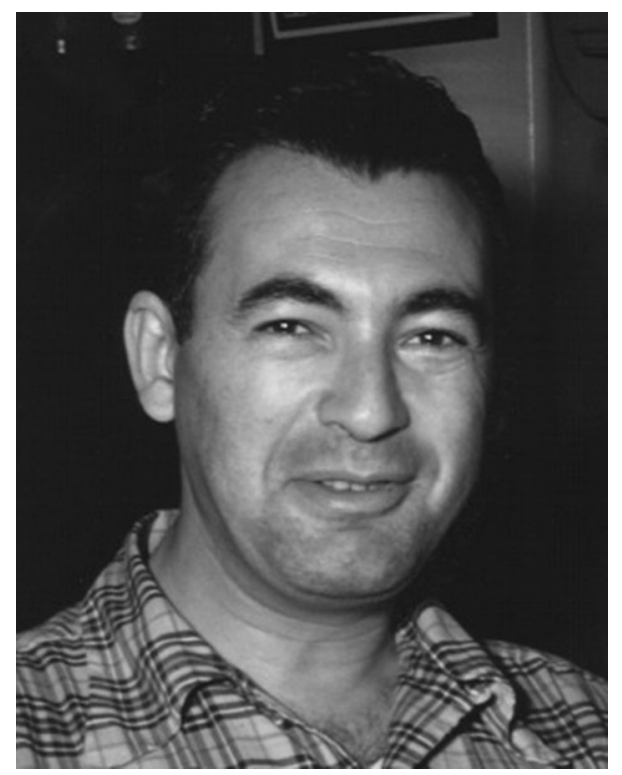

Fig. 16 Saul Winstein in 1951 (photograph by and courtesy of J. D. Roberts)

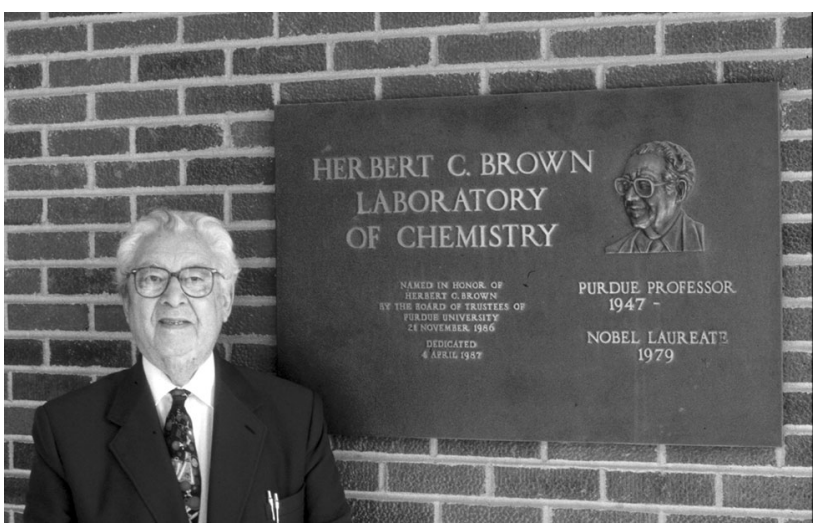

Fig. 17 Herbert C. Brown in 1995 in front of the plaque of the Herbert C. Brown Laboratory of Chemistry at Purdue University (photograph by the author)

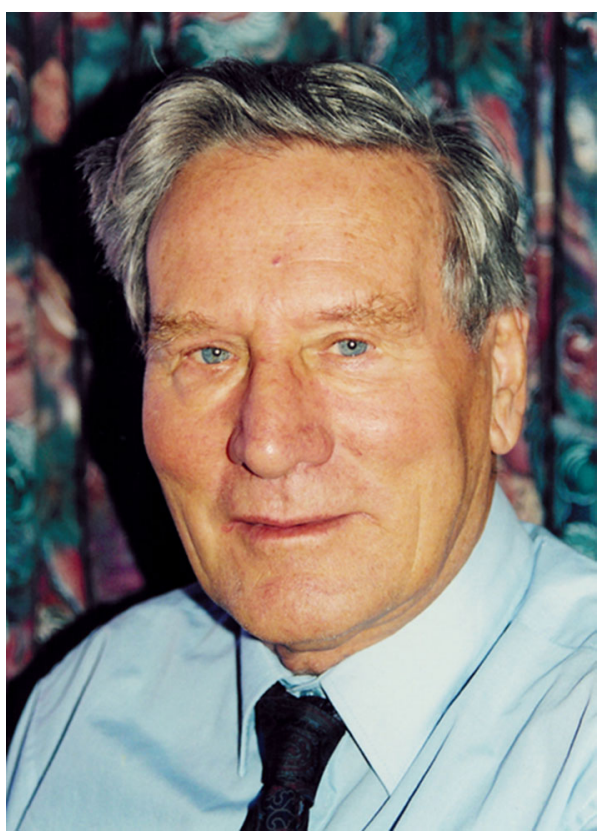

Fig. 18 Ronald J. Gillespie in 1998 in Austin, TX (photograph by the author)

date equipment, such as a high frequency NMR machine, Gillespie moved [11]. He then welcomed Olah's technician to run Olah's samples on his NMR equipment. Gillespie's laboratory was not the only one that assisted Olah and his group with NMR spectroscopy during Olah's industrial activities.

Gillespie's and Olah's research interests had an important overlapping area, and that was the superacids. The Harvard professor James B. Conant coined the name superacids for very strong acids as early as 1927, but he did not define their strength. Gillespie did just that in the 1960s, and according to him superacids are protic acids stronger than $100 \%$ sulfuric acid. Gillespie did a great deal of pioneering work in the superacid field. Olah recognized 
this to the extent that according to him, "Had the Nobel Prize been given for superacids, Ron in my opinion-as he well knows-should have certainly been included" [12]. However, the Nobel Prize was given for Olah's discoveries in carbocation chemistry, and it was, most deservedly, an unshared award.

In hindsight, it was almost inevitable that sooner or later Olah would find his way back to academia. This happened in 1965 when he moved to Cleveland as Professor and Chairman of the Department of Chemistry of Western Reserve University and he stayed in Cleveland for a decade (Fig. 19). He showed his acumen as an organizer, but he never slowed down in his research and fulfilled enthusiastically his teaching duties as well. The five portraits on the wall of his Cleveland office demonstrated his loyalty and his sense for the importance of continuity. When in 1996, he was asked the question: "Who is your biggest influence/hero and why?," his response was: "Hans Meerwein, who never considered himself a 'hyphenated' chemist and contributed much to synthetic, as well as mechanistic chemistry" [7].

Olah strengthened the chemistry department and by far not only through his own activities and those of his group. For example, he invited his fellow émigré chemist Miklos Bodanszky (Fig. 20), well known for his research in peptide chemistry and for his monographs in the field. As an organizer, Olah had an eye for the obvious that is sometimes the most difficult to notice: Across from his department, there was another chemistry department with only a parking lot between them. The other chemistry department belonged to the Case Institute of Technology. Within a couple of years, at Olah's initiative, the two departments joined and the merger was so successful that subsequently

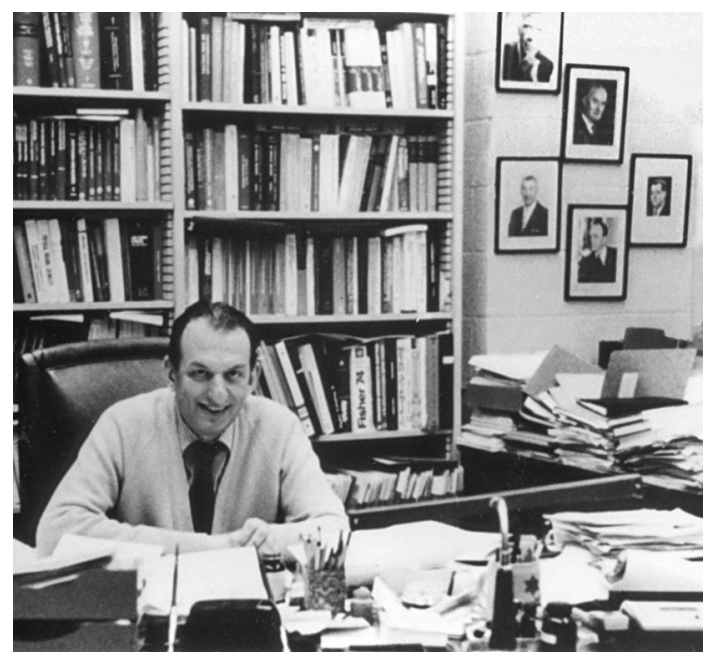

Fig. 19 George A. Olah in 1976 in his office in Cleveland. The pictures on the wall are of Hans Meerwein, Christopher K. Ingold, Saul Winstein, Herbert C. Brown, and Frank Whitmore. Courtesy of George A. Olah

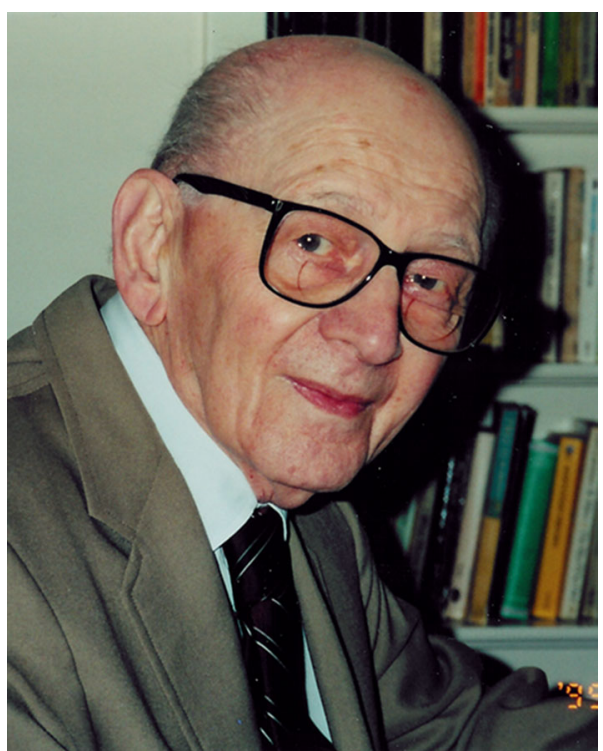

Fig. 20 Miklos Bodanszky in 1999 in Princeton (photograph by and courtesy of Eszter Hargittai)

the two schools joined as well, creating Case Western Reserve University as it is well known today. Olah served as chair for the joined department for a while, but then he let others run it.

Olah's acumen as researcher manifested itself also in bringing together all the techniques that he found necessary for solving the problems he was working on. It was not only a task of finding the right instrumentation but finding the right experts as well. At some stage it became obvious-at least to Olah-that the reliable solution of the carbocation problems could not happen without high-level quantum chemical computations. This is how his life-long cooperation and friendship developed with Paul von Ragué Schleyer (Fig. 21) [13]. Schleyer's computations contributed significantly to Olah's discoveries as the application of physical techniques and computation become jointly much more powerful than the sum of the two approaches when applied independently of each other. Schleyer's commitment to Olah's research lasted his entire research career and he returned to the question about the structure of the 2-norbornyl cation in one of his last papers. In it, he and his colleagues showed unambiguous X-ray crystallographic evidence, in concert with high-level computations, for the bridged, non-classical geometry of this carbocation [14].

\section{At the top}

In 1972, Olah published a seminal paper in the Journal of the American Chemical Society (Fig. 22) in which he described the general concept of carbocations. His 


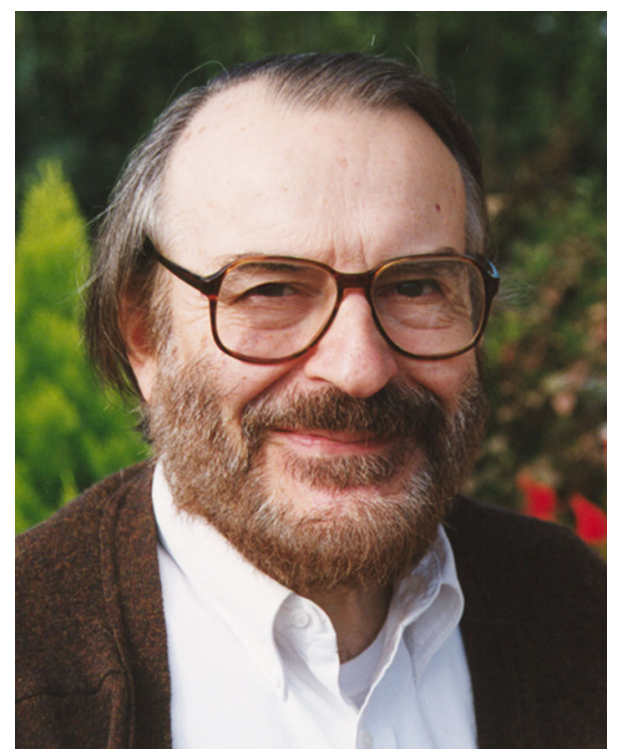

Fig. 21 Paul von Ragué Schleyer in 1995 in Vicksburg, MS (photograph by the author)

discovery of the reactivity of sigma donor single bonds in electrophilic reactions was nothing short of a revolution in hydrocarbon chemistry. The reactivity of these single bonds was "due to their ability to form carbonium ions via electron-pair sharing with the electrophile in two-electron, three-center bond formation." ([15], p. 808) There are a few characteristic drawings to illustrate a few aspects of the production and structure of carbocations after Olah. These are from a book series of the chemistry division of the Hungarian Academy of Sciences in which these drawings were reproduced (Figs. 23, 24, 25) [16].

In 2015, Olah published the second, updated edition of his autobiographical book, A Life of Magic Chemistry [4]. In it, he once again evaluated the significance of the norbornyl controversy. He did not formulate his views on this anew; rather, he referred to a conversation I recorded with him in 1996 in his office at the University of Southern California. The conversation was printed in full in 2000 ([10], pp 273-274) and the quoted passage was printed again in 2014 [17]. This is what Olah reproduced in 2015:

I came into it because around 1960 I discovered methods to generate positive organic ions, called now carbocations, as long-lived species, and we were able to take all kinds of spectra and establish their structure, including that of the norbornyl cation. In the course of this work I realized, however, that the problem has much wider implications. In the norbornyl ion the $\mathrm{C}-\mathrm{C}$ single bond acted as an electron donor nucleophile. In this particular case this happens within the molecule, that is, intramolecularly. This delocalization, which had been originally suggested by Winstein, was indeed there and we were able to

\section{The General Concept and Structure of Carbocations Based on Differentiation of Trivalent ("Classical") Carbenium Ions from Three-Center Bound Penta- or Tetracoordinated ("Nonclassical") Carbonium Ions. The Role of Carbocations in Electrophilic Reactions ${ }^{1 \text { n-e }}$}

George A. Olah

Contribution from the Department of Chemistry, Case Western Reserve University, Cleveland, Ohio 44106. Received February 26, 1971

\begin{abstract}
The general concept of carbocations (the suggested generic name for all cations of carbon compounds, in accordance with carbanion for negative ions) is defined based on the differentiation of tricalent ("classical") carbenium ions from three-center bound penta- or tetracoordinated ("nonclassical") carbonium ions. Carbenium ions usually have a planar or nearly planar $s p^{2}$ hybridized electron-deficient carbenium center, although linear vinyl and acyl cations are also known. The carbocation centers in carbonium ions are substantially less electron deficient penta- or tetracoordinated carbon atoms bound by three single bonds and a two-electron three-center bond (either to two additional bonding atoms or involving a carbon atom to which they are also bound by a single bond). Thus, in a carbonium ion the two electrons from the original $\pi$ or $\sigma$ bond are delocalized over three senters. Long-lived carbenium and carbonium ions can be experimentally differentiated from each other showing marked differences, for example, in their $\mathrm{nmr}$ and core photoelectron spectra. The structures of typical carbenium and carbonium ions, like alkenium ions, alkonium ions, alkenonium ions, cycloproponium ions, norbornonium ions, cyclopropylcarbonium ions, ethenebenzenium ions [bicyclo[2.5]octadienyl cations], are discussed in the conions, cyclopropylcarbonium ions, ethenebenzenium ions [bicyclo[2.5]octadienyl cations], are discussed in the con-
text of the general carbocation concept. It is emphasized that division of carbocations into limiting trivalent ("classical") and penta- or tetracoordinated ("nonclassical") categories is frequently arbitrary. In many carbocation systems an intermediate range of delocalization (partial carbonium ion character) must be considered, as is the case in the 2-methylnorbornyl cation. Both carbenium and carbonium ions play important roles in electrophilic reactions involving not only $\mathrm{n}$ - and $\pi$-but also $\sigma$-donor systems. The recently discovered general reactivity of single bonds ( $\sigma$ donors) in electrophilic reactions is due to their ability to form carbonium ions cia electron-pair sharing with the electrophile in two-electron, three-center bond formation. Subsequent cleavage to trivalent carbenium ions is followed by typical carbenium ion reactivity.
\end{abstract}

Fig. 22 Part of the first page of the pivotal paper in the Journal of the American Chemical Society in which Olah suggested the carbocation name and described the general concept and structure of carbocations [15] (C) 1972 American Chemical Society) 


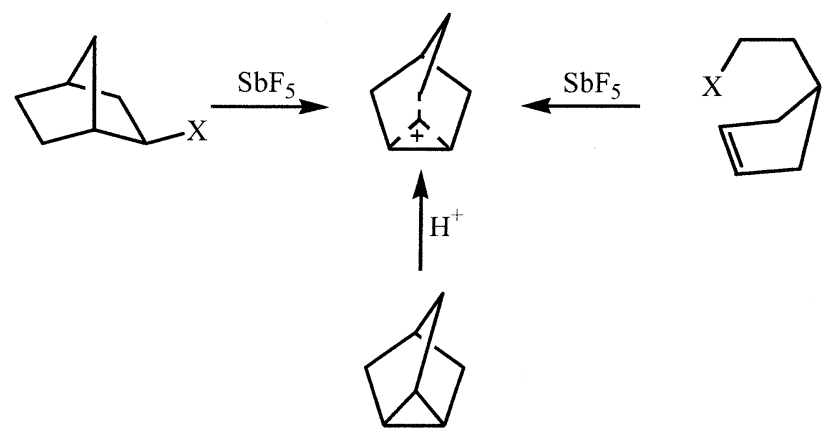

Fig. 23 A variety of routes to the long-lived non-classical 2-norbornyl ion ([16], p 35)<smiles>[CH]</smiles>

$\mathrm{H}_{3}^{+}$<smiles>CC</smiles>

methonium ion

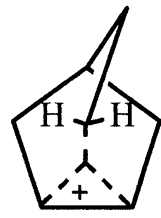

norbornyl ion<smiles>C[C+]1CC1</smiles>

corner protonated cyclopropane

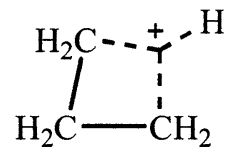

edge protonated cyclopropane
Fig. 24 Characteristic bonding examples in non-classical ions ([16], p 33)

see it directly for the first time. Later came, what I thought was a logical idea. The question what I asked myself one day was, if this can happen within the molecule, why can't it happen between the molecules? This led to the discovery of a wide range of electrophilic reactions of saturated hydrocarbons, that is, of $\mathrm{C}-\mathrm{H}$ or $\mathrm{C}-\mathrm{C}$ single bonds and the realization that carbon, under some conditions, can indeed bind five or even more neighboring groups ([4], pp 152-153).

\section{Structure of carbocations: The case of $\mathrm{CH}_{5}{ }^{+}$}

The overlapping interests of Olah and Gillespie were manifest also in the application of Gillespie's qualitative model for molecular geometry for testing some of Olah's unusual structures. Gillespie's valence shell electron pair repulsion (VSEPR) model or theory predicts the geometry of the molecule on the basis of the number of electron domains (bonding pairs, lone pairs, multiple bonds) in the valence shell of its central atom [18]. The predicted shapes and symmetries depend not only on the general number of electron domains but to various extents also on the nature of those domains, whether they are single bonds, lone pairs or multiple bonds. For the shape of $\mathrm{CH}_{5}{ }^{+}$, that is, for five electron domains in the valence shell, Gillespie's model would predict a trigonal bipyramid or a tetragonal pyramid-these two configurations are too close in energy to be distinguished unambiguously.

From the beginning, however, computations predicted a $\mathrm{C}_{\mathrm{s}}$ symmetry structure for the $\mathrm{CH}_{5}{ }^{+}$, which would correspond to the presence of three two-electron two-center bonds and one two-electron three-center bond (see, e.g., [4], p 158). This structure can be viewed either as having a high-degree of localization, or as having a fluxional character by exchanging the positions of the two-electron twocenter bonds and the two-electron three-center bond. If the $\mathrm{C}_{\mathrm{s}}$ symmetry structure corresponds to a sufficiently deep energy well, it can be observed in experiments, provided that the life-time of this structure is sufficiently long as compared with the interaction time for the physical technique employed. In this respect, the spectroscopic techniques, and NMR spectroscopy especially, are at disadvantage as compared with the diffraction techniques. The interaction times of the former are orders of magnitude longer than those of the latter. Alas, for practical reasons, the structure determination of $\mathrm{CH}_{5}{ }^{+}$by diffraction techniques would not be feasible.

Highly sophisticated high-resolution spectroscopic experiments on $\mathrm{CH}_{5}{ }^{+}$, as recent as 2015, have suggested the preeminence of geometries fully consistent with Olah's description of the structure (Fig. 26) [19]. There is a caveat though, because all the spectroscopic evidence point to the highly fluxional character of this carbocation: "the five proton swarm around the central carbon" [20].

Structural studies and considerations for the $\mathrm{CH}_{5}{ }^{+}$carbocation have a rich history (going back much before this nomenclature had been introduced) [21]. Historically, the structure of $\mathrm{CH}_{5}{ }^{+}$, called also the methonium ion, has presented a puzzle ever since it was first observed experimentally in 1952 in a mass spectrometric investigation [22]. Before the first computational studies, it used to be an assumption that the five hydrogens around the carbon would be equivalent or close to equivalent, which means a a VSEPR-type geometry. The early computational studies suggested this carbocation consisting of two parts; one, a pyramidal $\mathrm{CH}_{3}{ }^{+}$unit and the other, a hydrogen molecule bound to it. In other words, they were consistent with Olah's model of three two-electron covalent bonds and one two-electron three-center bond.

Thus, the VSEPR model could not predict the geometry of $\mathrm{CH}_{5}{ }^{+}$. In contrast, the geometry of monopositively charged carbocation $\left\{\left[\left(\mathrm{C}_{6} \mathrm{H}_{5}\right)_{3} \mathrm{PAu}\right]_{5} \mathrm{C}\right\}^{+}$containing fivecoordinate carbon has been found to be trigonal 
Fig. 25 The utilization of a variety of precursors for the preparation of the methylcyclopentyl carbocation ([16], p 27)

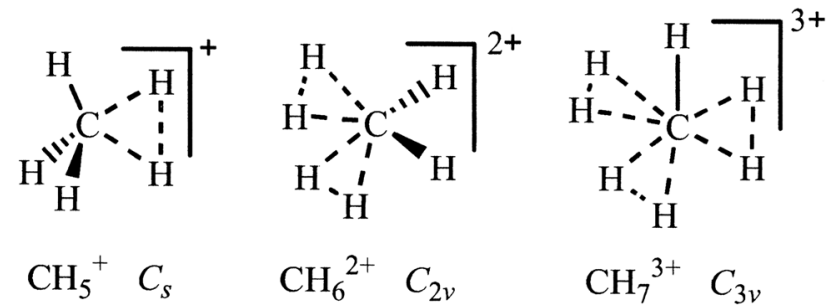

Fig. 26 Two-electron two-center bonds and two-electron threecenter bonds in protonated alkanes ([16], p 38)

bipyramidal in agreement with VSEPR predictions (Fig. 27). As Olah has suggested, this gold complex represents an isolobal analog of $\mathrm{CH}_{5}{ }^{+}$, hence the isolobal analogy would favor a trigonal bipyramidal geometry for $\mathrm{CH}_{5}{ }^{+}$as well, which, as we have seen, was not the case.
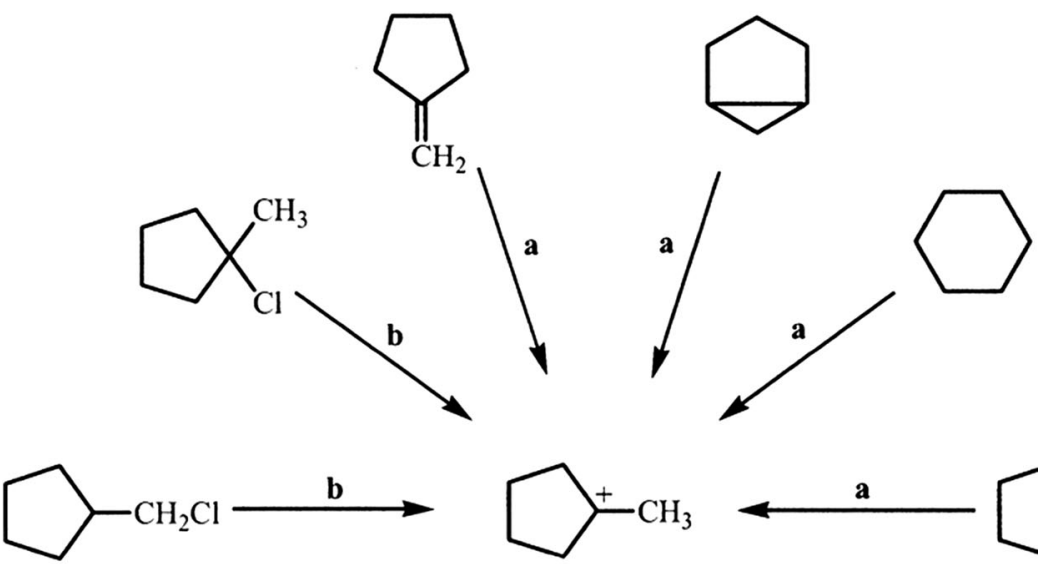

a<smiles>CC1CCCC1</smiles>

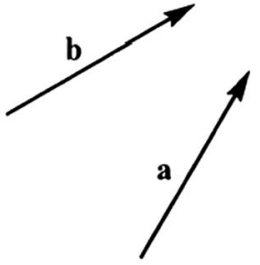

$x_{\mathrm{OH}}^{\mathrm{CH}_{3}}$

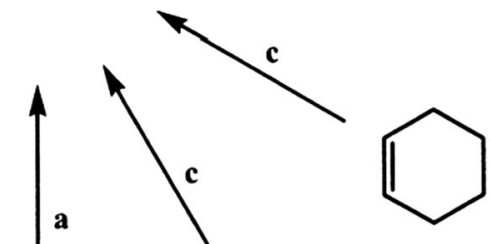<smiles>OC1CCCCC1</smiles>

$\mathrm{HSO}_{3} \mathrm{~F}-\mathrm{SbF}_{5}$ c $\mathrm{HF}-\mathrm{SbF}_{5}-\mathrm{SO}_{3}$

Considering the highly fluxional character of the $\mathrm{CH}_{5}{ }^{+}$ carbocation, it means not only the exclusion of VSEPRtype configurations but also a distinct $\mathrm{CH}_{3}{ }^{+}$plus $\mathrm{H}_{2}$ configuration in which three distinguished hydrogens form two-electron two-center bonds and two hydrogens participate in one two-electron three-center bond.

A discussion similar to the $\mathrm{CH}_{5}{ }^{+}$carbocation could be provided for the $\mathrm{CH}_{6}{ }^{2+}$ carbocation and the $\left\{\left[\left(\mathrm{C}_{6} \mathrm{H}_{5}\right)_{3}\right.\right.$ $\left.\mathrm{PAu}]_{6} \mathrm{C}\right\}^{2+}$ carbocation. Six equivalent electron domains would favor a regular octahedral geometry (of $\mathrm{O}_{\mathrm{h}}$ symmetry). In the gold complex, indeed, the six bonding directions point to the vertices of a regular octahedron in agreement with the prediction of the VSEPR model. In contrast, for the $\mathrm{CH}_{6}{ }^{2+}$ carbocation, again, the computations have suggested the presence of two two-electron covalent bonds and two two-electron three-center bonds.

Fig. 27 The trigonal

bipyramidal monopositively charged carbocation $\left\{\left[\left(\mathrm{C}_{6} \mathrm{H}_{5}\right)_{3} \mathrm{PAu}\right]_{5} \mathrm{C}\right\}^{+}$and the octahedral dipositively charged carbocation $\left\{\left[\left(\mathrm{C}_{6} \mathrm{H}_{5}\right)_{3} \mathrm{PAu}\right]_{6} \mathrm{C}\right\}^{2+}([16]$, p 38)
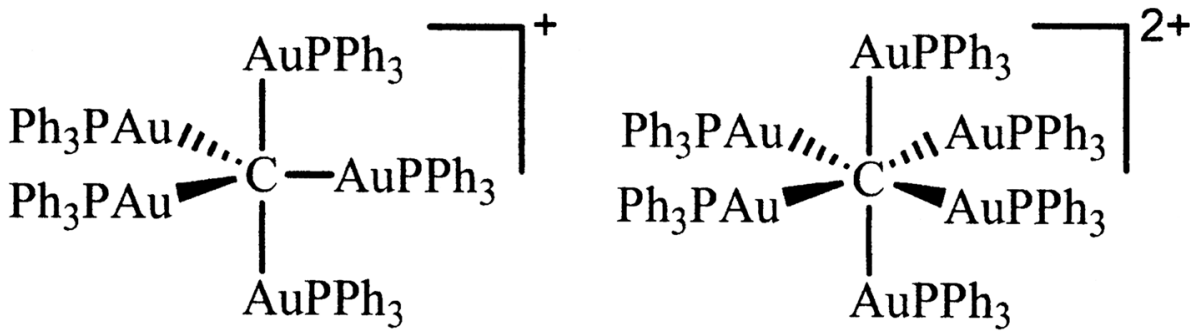
There is then the $\mathrm{CH}_{7}{ }^{3+}$ carbocation with one two-electron covalent bond and three two-electron three-center bonds.

Here, we are dealing with hypercarbons, though not with hypervalent carbons! The distinction is important. Carbon has no d orbitals available, hence it cannot extend its valence shell; it can only extend its coordination. Thus the correct reference to it is hypercoordinated carbon rather than hypervalent carbon. ([4], p 160)

We still do not know the structure of $\mathrm{CH}_{5}{ }^{+}$in full, but by now we do not know it at a much higher level of sophistication than before. One of the leading spectroscopists of this and similar species, Takeshi Oka of The Enrico Fermi Institute of the University of Chicago, called $\mathrm{CH}_{5}{ }^{+}$"the 'enfant terrible' of chemical structures." According to Oka, its theoretical understanding "will take at least a few more decades"! [20].

\section{The Nobel Prize}

In 1977, Olah and his group moved to the University of Southern California (USC) at Los Angeles. There he developed a research institute known today as the Loker Hydrocarbon Research Institute. It focuses its research efforts in a single well-defined area. This is unusual for the American university setting, but it is not unlike some European research laboratories of science academies. Olah has emerited from the directorship, which G. K. Surya Prakash took over from him, and Olah has continued with the title of Founding Director. Donald P. and Katherine B. Loker were the principal benefactors of the Institute but others have contributed generously to it as well. Olah's Nobel Prize brought a great deal of publicity to the Loker Institute, but the Institute had been operating with great intensity and efficacy for years.

George A. Olah received the Nobel Prize in Chemistry for 1994. It was an unshared award, which is not too common as far as recent science Nobel Prizes go. On the other hand, awarding Olah the Nobel Prize and an unshared one at that met with universal satisfaction, which is also not too common. It was obvious to all that he deserved it and deserved receiving it alone. The official motivation for the prize was terse and even sounded a little noncommittal: "for his contribution to carbocation chemistry." I would not just call his works "contributions;" rather, they were bona fide discoveries.

The presentation speech by Salo Gronowitz, the Chairman of the Nobel Committee for Chemistry at the award ceremony gave a more direct description of why Olah received the award. He said, in part, "Olah's discovery resulted in a complete revolution for scientific studies of carbocations, and his contributions occupy a prominent place in all modern textbooks of organic chemistry."
Further, Gronowitz noted: "Olah demolished the dogma that carbon in organic compounds could at most be tetracoordinated, or bind a maximum of four atoms" [2].

Gronowitz stressed that "Olah found that superacids were so strong that they could donate a proton to simple saturated hydrocarbons, and that these penta-coordinated carbonium ions [in Olah's nomenclature, carbocations] could undergo further reactions" [2]. In other words, even a carbon-carbon single bond or a carbon-hydrogen single bond could become an electron donor under the impact of an extremely strong proton donor, that is, in the presence of superacids. There is no doubt that Olah recognized the significance of his discovery for the whole of chemistry as he stated what we chose as the motto for this overview: "The realization of the electron donor ability of shared electron pairs could one day rank equal in importance with G. N. Lewis' realization of the electron donor unshared pairs" ([1], first pronounced in Olah's 1972 paper [15]).

The Nobel Prize in Chemistry is supposed to be given specifically "to the person who shall have made the most important chemical discovery or improvement" according to Alfred Nobel's Will (Fig. 28). This stipulation is preceded by a general one applicable to all categories of the prize: the awardees "shall have conferred the greatest benefit on mankind." Of course, even a discovery of purely fundamental nature with no foreseeable practical applications may qualify for conferring great benefits on mankind (the more so that seldom are there even purely fundamental discoveries that would not become eventually the roots of practical applications). However, it is always an advantage for the award selection if a discovery will have already shown direct benefits for improving the lot of humankind by the time of the Nobel Prize. Salo Gronowitz pointed out such features of Olah's discoveries in his presentation speech. Here are two examples from that speech: One that [Olah's] "discoveries have led to the development of methods for the isomerization of straight chain alkanes, which have low octane numbers when used in combustion engines, to produce branched alkanes with high octane numbers." Another is "With superacid catalysis it is also possible to crack heavy oils and liquefy coal under surprisingly mild conditions" [2].

This synergy of fundamental discoveries and their practical applications has continued shaping Olah's activities ever since the Nobel Prize as well. He decided not to sit on his laurels but continue his work and the practical applications may have taken up an even greater share of his activities since the Nobel distinction than before. This was so not necessarily by design, but because he had reached a stage in his research when the application of the vast amount of accumulated fundamental knowledge became almost inevitable. Thus, for example, to utilize the possibilities of "hydrogen economy," and to utilize them safely, 


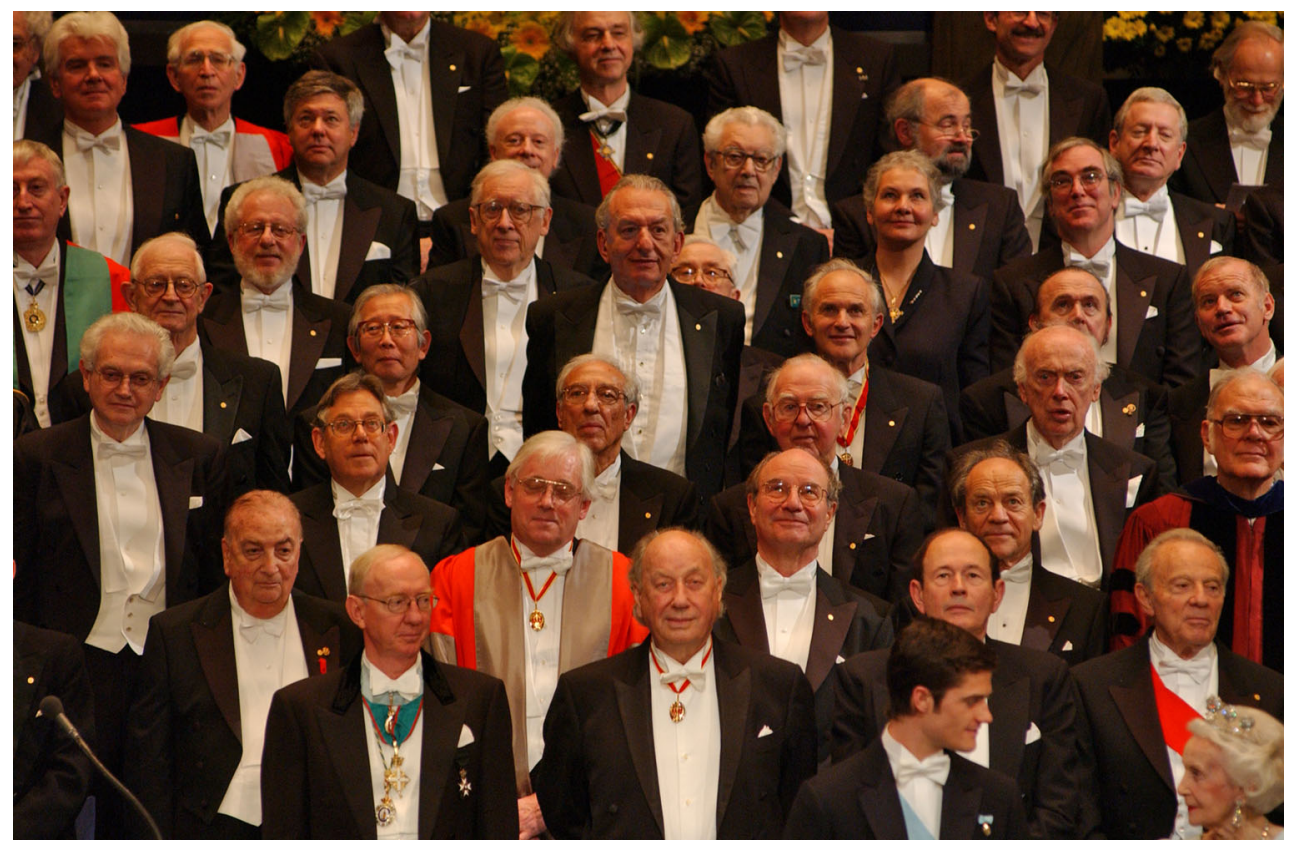

Fig. 28 A group of Nobel laureates at the Award Ceremony in Stockholm on December 10, 2001 (Photo by Hans Mehlin, (c) The Nobel Foundation, reproduced with permission). Row 7 Klug, X, Huber, X, Varmus (partly hidden), Bishop; Row 6 Blobel, M.S. Brown, Goldstein, H.C. Brown, Neher, Gilman; Row 5 Doherty (partly hidden), Heeger, Pople, Lewis (partly hidden), Nüsslein-

Olah proposed storing the hydrogen in the form of methanol-this has become known as his "methanol economy." He recognized the utility of this approach at several levels. It is not only good storage; its production by reduction of the carbon dioxide in the atmosphere helps to counter global warming. The development of the direct methanol fuel cell was a natural outcome of these efforts. Olah's updated autobiographical volume provides detailed and readable accounts of the methanol economy and the methanol fuel cell.

\section{Secrets, not classified}

One wonders if there is any secret that would be the clue to Olah's great success. In fact, there appear to be many such secrets, fortunately, none of them is classified, and here we mention a few. Of course, every scientist must travel his or her own road and there is no generally valid single route to recommend. Olah benefitted from a broad-based education. That his interest in chemistry came relatively late in his youth meant the development of his great interest in reading and in history.

It is instructive to follow the carbocation story in perspective with Olah as a knowledgeable guide. Even in possession of an unshared Nobel Prize he is sufficiently humble to give credit where it belongs and go back to the
Volhard, Wieschaus; Row 4 MacDiarmid, Shirakawa, Olah, Kroto, Schally (partly hidden), Mullis; Row 3 Nirenberg, Crutzen, E.H. Fischer, E.G. Krebs, Watson; Row 2 Benaceraff, Walker, Gilbert, T.N. Wiesel, Rowland; Row 1 Samuelsson, Vane, Edelman, Jacob; Row 0 Two members of the Royal Family: Prince Carl Philip and Princess Lillian

roots of his science ([4], pp 72-76). As early as 1899, Julius Stieglitz at the University of Chicago raised the question of the possibility of ionic carbon compounds. This was an isolated episode that did not generate any follow up although Stieglitz was an influential chemist. Just as an aside, Herbert C. Brown, who has figured in Olah's story above, attended Stieglitz's lectures years later. Brown referred to his interactions with his professor in this way "That began my acquaintance with Julius Stieglitz, one that changed my life" ([10], p 255).

In the early 1900s, subsequently, several researchers produced and described compounds that could be interpreted as having ionic carbon in them. Hans Meerwein discovered in the 1920 s that there are reactions that, while both the reactants and the products are covalent compounds, may have ionic intermediates (carbocations, in today's nomenclature). Still in the 1920s, Ingold, Hughes and their associates discussed further the role of carbocations in reactions.

Olah gives much credit to Frank Whitmore who in the 1930s established the transient role of the ionic intermediates that could not be observed directly, but just had to be there. Sadly, Whitmore's ideas met with so much disbelief that he could not use the trivial notation of cationic carbon species in his papers published in the Journal of the American Chemical Society. No wonder, there is loneliness for true discoverers. 
In subsequent years, the scenery was changing and broadly recognized chemists took up the problem of cationic carbon species to which they ascribed the presence of transient intermediates in some organic reactions. The famous debate between Winstein and Brown developed, and the conditions had gradually become ripe for Olah's discoveries. With Saul Winstein's untimely death in 1969, Olah had to take up Winstein's role and the discussions continued to 1983 when there was no longer any doubt that there was nothing more to argue about; the idea of the nonclassical ion presence had been proved unambiguously.

Olah though did not find the debates superfluous, because they have contributed to a better formulation of his discoveries. Olah appreciated the utility of criticism and he fully embraced what another Hungarian-born American Nobel laureate Georg von Békésy advocated in 1960 about the need of a few selfless enemies: "[One] way of dealing with errors is to have friends who are willing to spend the time necessary to carry out a critical examination of the experimental design beforehand and the results after the experiments have been completed. An even better way is to have an enemy. An enemy is willing to devote a vast amount of time and brain power to ferreting out errors both large and small, and this without any compensation. The trouble is that really capable enemies are scarce; most of them are only ordinary. ... Everyone, not just scientists, needs a few good enemies" [23]. Olah noted that the term adversaries would be a more proper term than enemies in this case. As it happened, nobody could stay long even to be an adversary to Olah, and his former adversaries have become his friends.

"The idea that ionization of alkyl fluorides to stable alkyl cations could be possible with an excess of strong Lewis acid fluoride that also serves as solvent first came to me in the early 1950 s while I was still working in Hungary..." ([4], p76) Here Olah magnanimously dates the origin of his road to success back to his tenure at the Budapest Technical University. His direct observation of the long-lived carbocations, called also persistent, happened in the late 1950 s at the Sarnia, Ontario, Dow Chemical laboratory. Thus, these two pivotal steps came about in two supposedly unlikely places for important fundamental research. It is not surprising that Olah in his autobiography shares his wondering about the advantages and disadvantages of the famous research universities and the venues he had labored in from Budapest via Sarnia and Cleveland, to Los Angeles. He offers encouraging words to those that, like himself, were not born with a silver spoon as far as research conditions were concerned.

It is a proof of Olah's greatness that if the conditions were not around, he created them. Witness to this the Loker Hydrocarbon Research Institute - a unique institution for an American university setting. He must have been a persuasive individual who could share his enthusiasm and dedication with people of means that were outside of chemistry and outside of science. Hydrocarbon chemistry may have not sounded too exciting even to many chemists and yet Olah could convince people of business that it was. He was right, of course; it is easy to see this in hindsight. Olah has had loyal friends and supporters and he has always been a loyal mentor, teacher, and colleague. When he was escaping from Hungary with his wife and little child, he was also thinking of his associates. I have had limited personal interactions with Olah, but even being far outside of the center of his activities I felt his care in the warmest of ways. How privileged it could have been to be closely associated with him. Olah states it unequivocally, "I have always put great importance on loyalty" ([4], p 85).

Olah always gave priority to research over positions and was "never bitten by the bug that makes many people feel important by exercising power." ([4], p 87) He rarely held administrative positions, except for the chair in Cleveland and the directorship of the Loker Institute. He held that the people who do not really want to give up their research and teaching make the best university administrators, because they have the intention and a place to return to their natural calling when their administrative tenure is over. He did not decline invitations to join various committees. However, while in the committee, he freely spoke his mind and this he found to be a foolproof method of never getting asked back to the committee again.

Olah always took teaching duties seriously and in his teaching, he conveyed his personal experience as a researcher. He maintains that good teaching supposes successful research activities. He makes this general comment that monies for education should not be considered expenses; rather, they should be considered investment [24]. He spoke about this at the University of Szeged in Hungary where the sources for education are in the state budget and politicians tend to decrease these sources for education first when the budget has to be cut.

\section{Legacy}

Olah has continued his interest and his participation in his science and human affairs, but approaching 90 it is inevitable that the question of legacy comes to mind. Olah is leaving a multifaceted and rich legacy. When reviewing his legacy it becomes clear that his resolving the famous Winstein-Brown dispute is fading away. In contrast, his discoveries that made the resolution of the dispute possible shine in ever increasing intensity. Olah applied the extremely strong superacids to prolong the lifetime of carbocations and his realization of the electron donor ability of 
shared electron pairs opened a new direction in organic chemistry-one may wonder whether the same realization would not open new vistas in inorganic chemistry as well. Olah's new chemistry led to the creation of countless new compounds and he has enhanced the practical applications of newly synthesized substances. This did not just happen; Olah has always had an eye for and interest in practical applications. The culmination of his efforts in this aspect was the emerging methanol economy for which future developments will be the measure of the scale of its success.

The mention of success brings us to an exchange with Olah I had in 2003 about its meaning for him. This is what he had to say in response to my query:

Success in science it looks to me means different things to different people. Many judge it in outside recognition of someone's work (prizes, membership in academies, honorary degrees, quotation numbers etc.). These may please the ego, but frankly are only trimmings. What I always felt is important is your inner satisfaction. After all, you should know best, if you are honest about it, whether you had achieved something in your scientific field, which has some lasting importance to our knowledge and understanding. If unexpectedly this can have also some application and benefit to society it adds to the feeling of success. However, most scientists are generally quite selfish and are inquiring because of their personal interest in a topic, which drives them not necessarily because they want to do something for society. Some of course judge success also based on material aspects (i.e. making money) but frankly, this never tempted me [25].

His books have a considerable place in Olah's legacy as this is similarly valid for many scientists. When I asked James D. Watson of the DNA double-helix fame about what he expected to be his longest ranging impact, his response was: "Probably my books" [26]. Watson thought that the DNA discovery "was just waiting to be made," but as for his Double Helix book, it "was probably unlikely to have been written by anyone beside myself." The relationship of books and discoveries may be different in Olah's legacy, but his books have undeniable importance. They have closely followed his progress in research. Whenever he completed his work in one research area, a summarizing monograph or an edited volume followed. This makes it possible to compile an approximate progression of his research career on the basis of these books. It started with his treatise on theoretical organic chemistry, on which he worked in Budapest and completed in Canada, to appear then in German in 1960. This was also part of his learning process. A selection of more research oriented volumes follows here without co-authors and co-editors and without full bibliographic references, which can be found elsewhere, for example in Olah's autobiographical volume. These books started appearing right from the start of Olah's research career.

Friedel-Crafts and Related Reactions (edited, in four volumes, 1963-1965)

Carbonium Ions (edited in four volumes, 1968-1973)

Carbocations and Electrophilic Reactions (1973)

Friedel-Crafts Chemistry (1973)

Halonium Ions (1975)

Superacids (1985)

Hypercarbon Chemistry (1987, updated 2011)

Nitration: Methods and Mechanisms (1989)

Cage Hydrocarbons (edited, 1990)

Electron Deficient Boron and Carbon Clusters

(edited, 1991)

Chemistry of Energetic Materials (edited, 1991)

Synthetic Fluorine Chemistry (edited, 1992)

Hydrocarbon Chemistry (1994; 2004)

Onium Ions (1998)

A Life of Magic Chemistry (2000, updated 2015)

Across Conventional Lines (edited, selected papers,

two volumes, 2003)

Carbocation Chemistry (2004)

Beyond Oil and Gas: The Methanol Economy (2006, updated 2009)

Superelectrophiles and Their Chemistry (2008)

Superacid Chemistry (2009)

Across Conventional Lines (edited, selected papers, third volume, 2014)

The synergy of fundamental science and the applications of its achievements is another important component in Olah's legacy. One might think that hydrocarbon chemistry is such a field that by its nature is close to practical aspects. However, some scientists in purely fundamental areas may also be more interested in practical applications than others. Eugene P. Wigner and John von Neumann, for example, were theoreticians, yet they were eager to find challenges related to applications, especially when they sensed the need for them [27]. For von Neumann, it meant primarily building computers and for Wigner, to use his knowledge of materials to help developing nuclear reactors. I am not suggesting that the shared origin and the shared life experience of Olah, Wigner, and von Neumann played a role in their shared interest in turning their scientific acumen into practical use, but the thought has crossed my mind.

I consider it part of Olah's legacy, the example he has set before others with his human demeanor. He has demonstrated that even a great scientist can stay a caring human being, a loyal friend, and an individual dedicated to 
assist others. He demonstrated tremendous inner strength when just surviving the last life-threatening months of persecution in 1945, he caught up with his school duties and passed his matriculation examinations at the Gimnázium of the Piarist Order. He then began his studies at the Budapest Technical University without any interruption let alone skipping a year, which could have been understandable. He succeeded in overcoming all barriers in the gradually hardening communist dictatorship of the early 1950s. As a refugee, he used the London sojourn of his family to build interactions with fellow scientists that would soon become useful especially during his tenure at the Dow Chemical industrial laboratory. When it became clear that no academic appointment would be available, he adjusted himself to the conditions of an industrial laboratory; built up his fundamental research after-hours; and in addition to fulfilling his duties, he functioned also as if it were an academic research venue, holding research seminars and attracting world-renowned scientists for visits.

His associates and disciples have always had a special place in Olah's life and activities. It was so during his Budapest years and it was so when he was making his escape with his family and his associates. It was also so from the start of his career in North America, and later in the Loker Hydrocarbon Research Institute. His care for his associates was always present regardless of his difficulties in securing a job, raising a young family, and overcoming all barriers that came his way. He concerned himself with the professional progress of his disciples and about the well-being of his students. Just an atypical example of the use of prize monies for an American professor: In 1979, the American Chemical Society presented Olah with the Award for Creative Work in Synthetic Organic Chemistry. He "used the prize money to send his students and postdoctoral researchers on a vacation to Hawaii" [28].

Wisdom and gaiety helped Olah to overcome difficult situations in his career. Although he states that "Human nature helps to block out memories of hardship and difficulties," ([4], p 294) some crept through even into his autobiography. It is telling that he considered hardship as character-building, but there was a limit to how much of it he wanted to tolerate. He remembers that "personal attacks and criticism which frequently came along were at times not easy to take" ([4], p 268). Early on, Olah received the lesson that being successful, even mildly successful, will generate envy. There were always some who would enjoy seeing him and his group failing. It may have helped him that he had experienced this kind of responses a great deal before his immigration. It is quite telling that the English language has no succinct equivalent to the German word

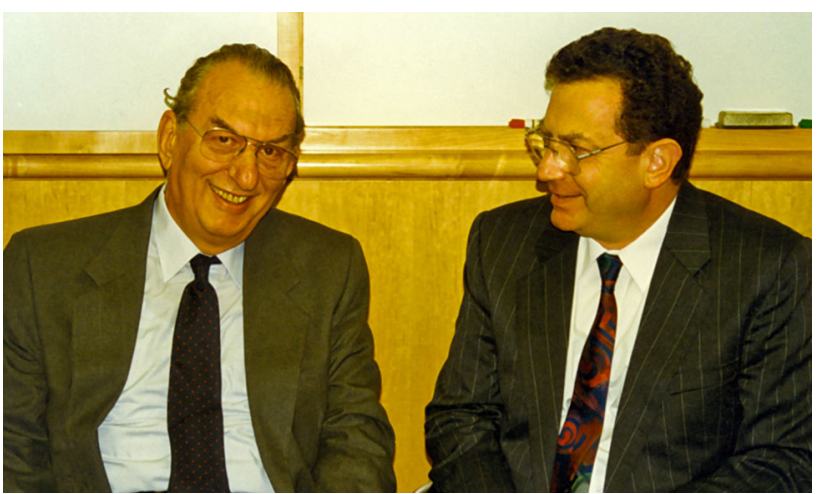

Fig. 29 George A. Olah and Istvan Hargittai on February 20, 1996, the day of the Inaugural George A. Olah Lecture at the University of Southern California (photograph by and courtesy of Magdolna Hargittai)

"Schadenfreude" (enjoyment obtained from the troubles of others). As Olah took setbacks and difficulties in stride, he did not allow Schadenfreude to get in the way.

Olah has found great joy in chemistry, and chemistry has remained the focus of his attention throughout. However, this did not prevent him from seeing the beauty of the rest of the world surrounding us. I single out his interest and fascination with the concept of "Symmetry," which is present in both science and the arts, and serves to connect them. This played a role in our personal interactions, which started before his Nobel Prize, a fortunate circumstance, because the number of a Nobel laureate's friends usually grows exponentially after the award, but the friendships that had begun before it usually prove to be stronger.

When in the spring of 1995 George and Judy visited us in Budapest, we talked, among others, about the symmetry concept. My wife and I had already been producing books about symmetry, first about symmetry in chemistry and, eventually, about symmetry everywhere else [29]. George invited me to give a lecture on symmetry at his university in February 1996 (Fig. 29). By the end of December 1995, everything was settled for this event planned for February 20, 1996. At that point, the chair of the USC chemistry department informed me that they were setting up a George A. Olah annual lectureship and decided to transform my presentation into its inaugural lecture. This is how it happened that my talk as "The 1st George A. Olah Lecture in Chemistry" on February 20 at USC was about symmetry. Plenty of chemistry found its way into this presentation [30].

Acknowledgments I appreciate the kind assistance I received in the preparation of this Editorial from Anders Bárány, Krisztina Batalka, Sándor Görög, Balazs Hargittai, Magdolna Hargittai, Diána Hay, Bálint Horváth, András Koltai, George A. Olah, Éva Sz. Kovács, Jonna Petterson, Zoltán Varga, Bob Weintraub, and Irwin Weintraub. 


\section{References}

1. Olah GA (1994) My search for carbocations and their role in chemistry. Nobel Lectures in Chemistry 1991-1995. World Scientific, Singapore, pp 149-176; actual quote and references, p 173

2. Gronowitz S (1997) Presentation speech at the Nobel Award Ceremony (in 1994). Nobel Lectures in Chemistry 1991-1995. World Scientific, Singapore, pp 139-140

3. Private communication from George A. Olah to Sándor Görög by e-mail, July 16, 2013

4. Olah GA (2015) A life of magic chemistry: autobiographical reflections including post-nobel prize years and the methanol economy. Second updated edition (with Mathew T). Wiley, Hoboken

5. Hargittai I, Hargittai M (2015) Budapest scientific: a guidebook. Oxford University Press, Oxford, p 288

6. Private communication from George A. Olah by e-mail, September 10, 2013

7. Chemistry \& Industry 15 July 1996, in the "Personal Chemistry" column (p 529)

8. Jones DW (2001) Olah's organic odyssey. Chemistry in Britain August, p 44

9. Hargittai I (2013) Buried glory: portraits of soviet scientists. Oxford University Press, New York

10. Hargittai I (2000) Candid science: conversations with famous chemists (edited by Magdolna Hargittai). Imperial College Press, London, p 276

11. Hargittai I (2003) Candid science III: more conversations with famous chemists (edited by Magdolna Hargittai). Imperial College Press, London, pp 48-57

12. Private communication from George A. Olah in hard-copy letter, January 29, 2002

13. Hargittai I (2015) Paul von Ragué Schleyer (1930-2014). Struct Chem 26:1-4

14. Scholz F, Himmel D, Heinemann FW, PvR Schleyer, Meyer K, Krossing I (2013) Crystal structure determination of the nonclassical 2-norbornyl cation. Science 341:62-64

15. Olah GA (1972) The general concept and structure of carbocations based on differentiation of trivalent ("Classical") carbenium ions from three-center bound penta- or tetracoordinated ("Nonclassical") Carbonium Ions. The Role of Carbocations in Electrophilic Reactions. J Am Chem Soc 94:808-820

16. Oláh Gy (2008) Fél évszázadot felölelő, hagyományos határokon átlépő kutatások. A kémia újabb eredményei 100:17-59

17. Hargittai B, Hargittai M, Hargittai I (2014) Great minds: reflections of 111 top scientists. Oxford University Press, New York, p 194

18. Gillespie RJ, Hargittai I (2012) The VSEPR model of molecular geometry (Reprint edition; original edition 1991). Dover, Mineola, NY

19. Asvany O, Yamada KMT, Brünken S, Potapov A, Schlemmer S (2015) Experimental ground-state combination differences of $\mathrm{CH}_{5}{ }^{+}$. Science 347:1346-1349

20. Oka T (2015) Taming $\mathrm{CH}_{5}{ }^{+}$, the "enfant terrible" of chemical structures. Science 347:1313-1314

21. Schreiner PR (2000) Does $\mathrm{CH}_{5}{ }^{+}$Have (a) "Structure?" A tough test for experiment and theory. Angew Chem Int Ed 39:3239-3241

22. Tal'rose VL, Lyubimova AK (1952) Dokl Akad Nauk SSSR 86:909-912

23. von Békésy G (1960) Experiments in hearing. McGrawHill, New York, $\mathrm{p} 8$

24. George A. Olah's comments quoted in the newspaper Délvilág, June 28, 2003, pp 1 and 3

25. Private communication from George A. Olah by e-mail, August 18,2003

26. Hargittai I (2007) The DNA Doctor: Candid Conversations with James D. Watson. World Scientific, Singapore, p 37

27. Hargittai B, Hargittai I (2016) Wisdom of the Martians: in their own words with commentaries. World Scientific, Singapore

28. Wilson E (1997) Olah's 70th birthday draws devoted crowd. Chemical \& Engineering News December 22, p 43

29. Hargittai M, Hargittai I $(2009,2010)$ Symmetry through the Eyes of a Chemist (Updated Third Edition; previous editions, 1986 and 1995). Springer Science + Business

30. Hargittai I (1996) Symmetry in science and art-the chemical connection. The First George A. Olah Lecture in Chemistry. University of Southern California, Los Angeles, unpublished presentation 